\title{
Can immunotherapy be useful as a "functional cure" for infection with Human Immunodeficiency Virus-1?
}

Guido Vanham ${ }^{1,2^{*}}$ and Ellen Van Gulck ${ }^{1,3}$

\begin{abstract}
Immunotherapy aims to assist the natural immune system in achieving control over viral infection. Various immunotherapy formats have been evaluated in either therapy-naive or therapy-experienced HIV-infected patients over the last 20 years. These formats included non-antigen specific strategies such as cytokines that stimulate immunity or suppress the viral replication, as well as antibodies that block negative regulatory pathways. A number of HIV-specific therapeutic vaccinations have also been proposed, using in vivo injection of inactivated virus, plasmid DNA encoding HIV antigens, or recombinant viral vectors containing HIV genes. A specific format of therapeutic vaccines consists of ex vivo loading of autologous dendritic cells with one of the above mentioned antigenic formats or mRNA encoding HIV antigens.

This review provides an extensive overview of the background and rationale of these different therapeutic attempts and discusses the results of trials in the SIV macaque model and in patients. To date success has been limited, which could be explained by insufficient quality or strength of the induced immune responses, incomplete coverage of HIV variability and/or inappropriate immune activation, with ensuing increased susceptibility of target cells.

Future attempts at therapeutic vaccination should ideally be performed under the protection of highly active antiretroviral drugs in patients with a recovered immune system. Risks for immune escape should be limited by a better coverage of the HIV variability, using either conserved or mosaic sequences. Appropriate molecular adjuvants should be included to enhance the quality and strength of the responses, without inducing inappropriate immune activation. Finally, to achieve a long-lasting effect on viral control (i.e. a "functional cure") it is likely that these immune interventions should be combined with anti-latency drugs and/or gene therapy.
\end{abstract}

Keywords: HIV, SIV, Immune therapy, Functional cure, Therapeutic vaccine, CD8 T cells, Macaque trials, Human trials

\section{Review}

Introduction: functional cure and natural immune control of HIV

During last year's International AIDS Society (IAS) Conference (July 2011) the "Rome Statement for an HIV Cure" was issued, pleading for "the development of a functional cure which, without completely eliminating the virus from the body, would permanently suppress its replication and considerably diminish viral reservoirs,

\footnotetext{
* Correspondence: gvanham@itg.be

${ }^{1}$ Virology Unit, Department of Biomedical Sciences, Institute of Tropical Medicine of Antwerp, Nationalestraat 155, B-2000, Antwerpen, Belgium ${ }^{2}$ Department of Biomedical Sciences, University of Antwerpen, Antwerpen, Belgium

Full list of author information is available at the end of the article
}

possibly leading to the long-term remission of patients, in the absence of antiretroviral drugs" (see http://www. iasociety.org/Default.aspx?pageId=584). More recently (July 2012), the dedicated IAS Working Group organized a well-attended symposium in Washington "Towards an HIV Cure", accompanied by a "Perspective" paper in Nature Reviews Immunology. Two possibilities for cure were distinguished: "first, the elimination of all HIVinfected cells (a sterilizing cure); and second, the generation of effective host immunity to HIV that would result in lifelong control of the virus in the absence of therapy, despite not achieving the complete eradication of HIV (a functional cure)" [1]. The prototypical example of an HIV cure is the well-known "Berlin patient",

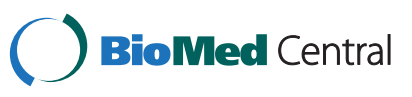


who, after elimination of his own immune system by irradiation in the context of acute myeloid leukemia treatment, was transplanted with hematopoietic stem cells (HSC) from a homozygous CCR5 delta32 donor and subsequently remained virus-free without any antiretroviral treatment for over 5 years at the time of writing [2]. Nevertheless, during the recent symposium, data were presented on some remaining detectable HIV DNA in rectal biopsies, despite having plasma RNA levels below 1 copy and a complete absence of viral DNA, RNA or cultivable virus from peripheral blood mononuclear cells (PBMC). Hence, this much-acclaimed patient is probably an example of a "functional" rather than of a "sterilizing" cure (S Palmer personal communication). As a consequence of this unique success story, several research groups are now attempting to knock out the CCR5 genes in various cell types, including HSC [3]. Results of syngeneic CCR5(-) HSC transfer in humanized mice indicate that, upon infection, HIV-1 viral levels are clearly lower, but not absent [4]. Since it remains uncertain whether this cumbersome genetic therapy will offer a cure for all patients [5], other strategies need to be considered, including immunotherapy and anti-latency drugs, as proposed by the Working Group (http://www.iasociety.org/Default. aspx?pageId=606).

\section{Role of HIV-specific immunity in viral control}

Several excellent reviews on immune mechanisms of HIV control have recently been published [6-8]. In the earliest phase of infection innate responses, including type-1 interferon (IFN- $\alpha / \beta)$ and Natural Killer (NK) cells partly control virus replication. Only after a few weeks do HIV-specific CD4 and CD8 T cell responses as well as antibody responses emerge and reduce viral load (VL) to a patient-specific setpoint [9]. For a long time, interleukin-12 (IL-12) has been thought to have an essential immune-regulatory role in the induction of a "Th1-skewed cellular response", characterized by an optimal interplay between IL- $2 / \mathrm{IFN}-\gamma$ producing CD4 helper and CD8 effector T cells, which is crucial for the adaptive phase on anti-viral responses [10].

Examples of the "naturally occurring" functional cure in HIV infection include the so-called "elite controller" (EC) HIV-1 patients, who are therapy-naïve but nevertheless keep their "viral setpoint" below 50 RNA copies per ml plasma [11]. In addition, rare non-controllers acquire a "secondary" controller status after prolonged "Highly Activate Antiretroviral Therapy" (HAART), initiated either in the acute phase [12,13] or, even more rarely, in the chronic phase $[14,15]$.Clearly, this uncommon phenomenon of "post treatment control" (PTC) is seemingly more easily induced if HAART is started in the acute as opposed to the chronic phase, pointing to a contribution of a less damaged immune system and/or a lower proviral reservoir.

Whereas the in-depth study of PTC is just beginning, more data are available on EC. Decreased viral replication capacity and genetic host factors have been identified in a percentage of EC. Unfortunately, these factors are largely impossible to operationalize with the present state-of-the art technology. However, an association has been found between viral control and HIV Gag-specific $\mathrm{CD} 4$ and $\mathrm{CD} 8 \mathrm{~T}$ cell responses, but not Env-specific T cells or Env-specific neutralizing antibodies, pointing to an important role for HIV-specific T cell immunity towards more conserved structural parts of the virus such as Gag $[16,17]$.

Effective CD8 T cells, capable of keeping the plasma viral load under control, are characterized by a central and effector-memory phenotype, low levels of aberrant activation and exhaustion markers (e.g. CD38 and programmed death (PD)-1), and preserved costimulatory receptors (e.g. CD28). Effective HIV-specific CD8 T cells produce multiple cytokines and effector molecules; they have preserved proliferative capacity; and their $\mathrm{T}$ cell receptors show high avidity and/or cross-reactivity, preferentially recognizing conserved epitopes in Gag, thus leaving little opportunity for immune escape $[16,17]$. Importantly, these CD8 $\mathrm{T}$ cells also show a high-avidity cytolytic potential against infected cells [18] and have the capacity to suppress viral replication in vitro $[19,20]$. These observations provide a rationale to attempt to develop strategies to enhance immune control by "therapeutic vaccination" $[11,21]$.

In order to induce and maintain this type of effective CD8 T cells, a well-coordinated interaction with dendritic cells (DC) and CD4 T cells is important [22]. HIVspecific CD4 $\mathrm{T}$ cells play an important role by producing "helper" cytokines, such as those triggering the "common $\gamma$ chain receptors" (IL-2, IL-7 and IL-21), as well as by upregulating costimulatory membrane markers such as CD40L as well as CD80 and CD86, which promote CD8 $\mathrm{T}$ cell survival, proliferation, cytotoxicity and virussuppressive capacity $[6,23]$. DC can directly activate CD8 $\mathrm{T}$ cells, but also induce effective CD4 $\mathrm{T}$ cell help to CD8 T cells. Therefore, harnessing the DC function to improve the quality of $\mathrm{T}$ cell responses against HIV can be an important mechanism in immunotherapy $[24,25]$.

\section{The danger of an activated immune system}

Progressive HIV infection is characterized by persistently increased levels of various soluble inflammatory markers, dysregulation of $\mathrm{T}$ cell surface markers, and upregulation of receptors for immune suppressor signals such as PD-1 and cytolytic T-lymphocyte antigen (CTLA)-4. This inappropriate immune activation is partly due to a persistent VL, but in addition endotoxins 
originating from microbial translocation through a "leaky gut" and "hypersensitivity" to type 1 IFN have been implicated (for review see [26]). A sizeable body of evidence suggests that this persistent "immune activation syndrome" constitutes a bad prognostic sign, independent from CD4 T cell count, plasma VL and cellular proviral load, even under suppressive HAART [27]. Unsurprisingly, inappropriate $\mathrm{T}$ cell activation is associated with increased susceptibility of CD4 T cells to infection and decreased $\mathrm{T}$ cell responsiveness to antigenic stimulation, including reduced IL-2 production, and increased apoptosis. This activation-induced "T cell exhaustion" conceptually limits the possibilities of immunotherapy and therefore it is important to provide sufficient costimulatory signals [28], without increasing susceptibility of target cells to HIV.

\section{The role of HAART and viral reservoirs}

HAART reduces VL and immune activation, and therefore it was hoped that long-term HAART would allow the immune system to recover its capacity to control the virus. A number of "structured treatment interruption" (STI) trials have indicated that while immune responses to HIV were boosted, the VL rebounded to pretreatment levels in most patients (except for the rare "secondary controllers" or PTC), suggesting that infectious virus is not a good antigen for immune therapy [29]. The fundamental problem to fully eradicate the virus is the persistence of a "latent" reservoir. Neither long-term treatment with classical HAART cocktails (based on reverse transcriptase and protease inhibitors) nor treatment intensification with newer integrase or entry-inhibitors can consistently reduce this reservoir (for review see [30]).

One proposed strategy for cure is to activate the latent provirus under coverage of HAART: the rescued virus will kill the producer cell, but cannot infect new targets. Many excellent reviews have been dedicated to this complicated challenge $[3,31,32]$. The $y$-chain cytokine interleukin-7 (discussed below for its immune stimulating potential) is currently under study for its potential to "purge" the latent HIV reservoir (ERAMUNE trial, http://www.clinicaltrials.gov). A number of pharmacological agents, including (combinations of) histone-deacytelase inhibitors, NF- $\kappa \beta$ activating agents and others have shown some HIV-rescuing activity in vitro. This has been accompanied, however, by global $\mathrm{T}$ cell activation and, until now, no convincing favorable clinical data have been reported [30]. Many pharmaceutical companies are currently screening compound libraries to find novel factors that could more potently and more selectively rescue the latent virus, but this topic is beyond the scope of the present review.
In the context of immunotherapy, however, antilatency drugs are relevant; even if they were unable to "purge" the reservoir by themselves. In fact, complete latency renders infected cells invisible to the immune system, precluding targeting by therapeutic vaccination. Anti-latency drugs could overcome this hurdle, because they induce expression of viral proteins that would mark the infected cells as targets for immune elimination $[33,34]$.

In conclusion, several principles can be proposed for immunotherapy. These include a non-specific enhancement of anti-viral immune responses by various immune stimulators, including type-1 IFN, IL-12 and the socalled common $\gamma$-chain signaling cytokines, related to IL-2. In addition, blocking antibodies against immune suppressive receptors such as PD-1 and CTLA-4 could also provide beneficial immune stimulation. On the other hand, a range of antigenic formats have been proposed to induce HIV-specific $\mathrm{T}$ cell responses, in order to elicit more effective CD8 $\mathrm{T}$ cell-mediated immune surveillance.

In the following paragraphs, we will explain the rationale of each strategy and then focus mainly on therapeutic vaccination trials in Simian Immunodeficiency Virus (SIV)-infected macaques and HIV infected patients, critically investigating their potential to complement (and ultimately replace) anti-retroviral drug therapy. Clearly, no definite strategy for a cure has been established yet, but encouraging results are emerging and the concepts are slowly but surely maturing.

\section{Non-antigen specific immune therapies}

An overview is presented in Table 1.

\section{Cytokine therapies}

Type-1 interferon During the acute phase of HIV infection, high levels of serum IFN- $\alpha$ are part of the innate antiviral response, as in vitro results showed that IFN- $\alpha$ indeed reduced HIV replication in both CD4 T cells and monocytes-macrophages. However, the role of type-1 IFN in HIV pathogenesis is rather ambiguous, since in the chronic phase, serum markers of increased IFN activity, such as neopterin and $\beta 2$-microglobulin have consistently been associated with a bad prognosis [49].

Based on the first premise (type 1 interferon $=$ antiviral), in vivo IFN- $\alpha$ treatment was attempted in the era before anti-retroviral drugs were available, but failed to provide benefit in Acquired Immune Deficiency Syndrome (AIDS) patients; whereas in infected patients with preserved immunity a trend to a better clinical outcome was noted. Later, IFN- $\alpha$ was combined with monotherapy or bi-therapy of nucleoside reverse transcriptase inhibitors (NRTI). A trend for increased antiviral effects 
Table 1 Non antigen-specific immune therapy

\begin{tabular}{|c|c|c|c|c|c|c|c|}
\hline Name Trial & Species & $\begin{array}{l}\text { Baseline patients } \\
\text { characteristics }\end{array}$ & $\begin{array}{l}\text { Type of immune } \\
\text { therapy }\end{array}$ & $\begin{array}{l}\text { Route and frequency of } \\
\text { administration }\end{array}$ & $\begin{array}{l}\text { Number of } \\
\text { patients }\end{array}$ & Outcome & References \\
\hline $\begin{array}{l}\text { Phase I dose } \\
\text { escalation trial }\end{array}$ & Human & HAART & IL-12 & sc, single dose & 47 & $\begin{array}{l}\text { Dose related increase in serum IFN- } \gamma \\
\text { levels, NK and CD8 T cell numbers. }\end{array}$ & [35] \\
\hline $\begin{array}{l}\text { Phase I randomized } \\
\text { placebo controlled }\end{array}$ & Human & HAART & IL-12 & $\begin{array}{l}\text { sc, multi dose twice weekly } \\
\text { for } 4 \text { weeks. }\end{array}$ & 56 & $\begin{array}{l}\text { Well tolerated at doses up to } 100 \mathrm{ng} / \mathrm{kg} \text {. } \\
\text { Dose related increase in neopterin levels. } \\
\text { No differences in other immunological } \\
\text { parameters or viral load }\end{array}$ & [36] \\
\hline $\begin{array}{l}\text { Three randomized } \\
\text { trials }\end{array}$ & Human & Mono- or dual treated & $\mathrm{IL}-2$ & iv intermittent 5 days regimen & 155 & $\begin{array}{l}\text { Higher CD4 T cell count, lower VL } \\
\text { and } 43 \% \text { reduction in risk of disease } \\
\text { progression or death. }\end{array}$ & [37] \\
\hline SILCAAT & Human & $\begin{array}{l}\text { HAART Low CD4 T } \\
\text { cell count }\end{array}$ & $\mathrm{IL}-2$ & $\begin{array}{l}\text { sc } 6 \text { cycles of IL-2 twice } \\
\text { daily for } 5 \text { consecutive days }\end{array}$ & 1695 & $\begin{array}{l}\text { Sustained effect on CD4 T cells without } \\
\text { affecting clinical progression }\end{array}$ & [38] \\
\hline ESPRIT & Human & $\begin{array}{l}\text { HAART High CD4 T } \\
\text { cell count }\end{array}$ & $\mathrm{IL}-2$ & $\begin{array}{l}\text { sc } 3 \text { cycles of IL-2 twice } \\
\text { daily for } 5 \text { consecutive days }\end{array}$ & 4111 & $\begin{array}{l}\text { Temporary effect on CD4 T cells without } \\
\text { affecting clinical progression. }\end{array}$ & [38] \\
\hline $\begin{array}{l}\text { ANRS } 119 \\
\text { randomized } \\
\text { clinical trial }\end{array}$ & Human & Therapy naïve & $\mathrm{IL}-2$ & $\begin{array}{l}\text { sc } 3 \text { cycles of IL2 for } 5 \\
\text { consecutive days }\end{array}$ & 130 & $\begin{array}{l}\text { Sustained increase in CD4 T cells without } \\
\text { affecting viral load. }\end{array}$ & [39] \\
\hline ANRS-NIH ILIADE & Human & HAART with high CD4 & $\mathrm{IL}-2$ & $\begin{array}{l}\text { sc } 3 \text { cycles of IL2 for } 5 \\
\text { consecutive days. ATI on } \\
\text { week } 24\end{array}$ & 148 & $\begin{array}{l}\text { Delay HAART resumption following } \\
\text { treatment interruption. No effect } \\
\text { on viral load. }\end{array}$ & [40] \\
\hline $\begin{array}{l}\text { Random placebo } \\
\text { controlled trial }\end{array}$ & Human & Therapy naïve & IL-7 & sc, single injection & 25 & $\begin{array}{l}\text { Increased numbers of circulating CD4 and } \\
\text { CD8 T cells. Transient increase in VL. }\end{array}$ & [41] \\
\hline \multirow[t]{7}{*}{$\begin{array}{l}\text { EudraCT (open label } \\
\text { phase } 1 / / \text { la) }\end{array}$} & Human & HAART & IL-7 & $\begin{array}{l}\text { sc repeated injections. Eight } \\
\text { doses } 3 \text { times a week }\end{array}$ & 13 & Expansion of naïve CD4 and CD8 T cells. & [42] \\
\hline & $\begin{array}{l}\text { Rhesus } \\
\text { macaque }\end{array}$ & Chronic SIV & IL-7 & sc 4 injections every 3 weeks & 9 & $\begin{array}{l}\text { Counteracts IFN-a induced lymphopenia. } \\
\text { Increasing circulating CD4 T cells. }\end{array}$ & [43] \\
\hline & $\begin{array}{l}\text { Indian rhesus } \\
\text { macaque }\end{array}$ & Chronic SIV + HAART & IL-15 & sc twice a week from day 0-day 42 & 16 & $\begin{array}{l}\text { Delayed viral suppression. Failed to enhance } \\
\text { antigen-specific CD4 T cell reconstitution at } \\
\text { mucosal and lymphoid sites. Upon ATI loss of } \\
\text { CD4 T cells more rapidly. }\end{array}$ & [44] \\
\hline & $\begin{array}{l}\text { Indian rhesus } \\
\text { macaque }\end{array}$ & Chronic SIV & IL-21 & $\begin{array}{l}2 \text { iv injections } 7 \text { days apart } \\
\text { and } 3 \text { sc doses } 23 \text { days } \\
\text { after } 2^{\text {nd }} \text { vaccination. }\end{array}$ & 7 & $\begin{array}{l}\text { Safe and well tolerated. Increased cytotoxic } \\
\text { potential of T cells, increased SIV antibody } \\
\text { production. }\end{array}$ & [45] \\
\hline & $\begin{array}{l}\text { Indian rhesus } \\
\text { macaque }\end{array}$ & Chronic SIV & Blocking Ab to PD-1 & IV & 14 & $\begin{array}{l}\text { Expansion virus specific CD8 T cells and } \\
\text { B cell activation. Reduction in plasma VL } \\
\text { and prolonged survival. }\end{array}$ & [46] \\
\hline & $\begin{array}{l}\text { Rhesus } \\
\text { macaque }\end{array}$ & Chronic SIV + HAART & Blocking Ab to CTLA4 & iv & 16 & $\begin{array}{l}\text { Increase CD4 and CD8 T cell responses } \\
\text { and drop of viral RNA. }\end{array}$ & [47] \\
\hline & $\begin{array}{l}\text { Indian rhesus } \\
\text { macaque }\end{array}$ & Chronic SIV + HAART & Blocking Ab to CTLA4 & iv & 10 & $\begin{array}{l}\text { No expansion SIV specific T-cells. Increased } \\
\text { activation of T cells and increased viral } \\
\text { replication at mucosal sites. }\end{array}$ & [48] \\
\hline
\end{tabular}


was noted, but this benefit was offset by rather serious flu-like side effects [50]. Once efficient HAART tritherapy became available, combinations with type 1 interferons were abandoned for the indication of HIV infection alone (though they are still in use for selected cases of chronic hepatitis and HIV co-infection).

Since elevated IFN- $\alpha$ levels are suspected to play a role in pathological immune activation, Zagury et al. attempted to immunize HIV patients against this cytokine. The subgroup of patients with a rise in anti-IFN- $\alpha$ antibodies had a significantly lower incidence of HIV-1related events compared with placebo recipients and vaccinees who failed to develop antibodies [51].

A different approach was used more recently with the anti-malarial drug chloroquine. Preliminary evidence in vitro and in vivo indicated that chloroquine reduces IFN- $\alpha$ production and decreases the level of immune activation [52]. A randomized double blind placebocontrolled trial in therapy-naïve patients, however, failed to show any favorable effect on immune activation and, unfortunately, did result in a greater decline in CD4 $\mathrm{T}$ cell count and increased VL [53].

Interleukin-12 A Th1/Th2 imbalance has traditionally been regarded as a hallmark of HIV-related immune dysfunction [54]. IL-12 represents the archetypical Th1 switching agent: it induces type II interferon (IFN- $\gamma$ ) production by $\mathrm{T}$ cells and NK cells and increases their cytotoxic capacity against virally infected cells [10]. A number of in vitro studies in PBMC cultures from HIV infected subjects confirmed that IL-12 increased Th1 responses [55,56]. Before the HAART era, two phase 1 studies of subcutaneous (sc) IL-12 were conducted in medically stable HIV-infected patients. Single doses of sc IL-12 between 30 and $300 \mathrm{ng} / \mathrm{kg}$ were reasonably tolerated and induced a dose-related increase of serum IFN$\gamma$, but failed to influence CD4 T counts or VL [35]. In a subsequent placebo-controlled multi-dose trial, IL-12 was tolerated in doses up to $100 \mathrm{ng} / \mathrm{kg}$, but again no effect on CD4 T counts or VL was observed [36]. Apparently, repeated IL-12 administration resulted in "tolerance", and overdosing could even result in paradoxical immune suppression through activation of $\mathrm{NO}$ production $[57,58]$. Nowadays, in many experimental immunization schedules with HIV antigens in either plasmid DNA or viral vectors, an expression cassette for IL-12 is being added, thus focusing IL-12 expression at the site of immunization and avoiding systemic side effects.

Common $\gamma$ chain signaling cytokines These cytokines include IL-2, -4, -7, -9, -13, -15 and -21 and bind to receptor complexes that include the so called common $\gamma$ signaling chain. Among these, IL-4, -9 and -13 skew the immune system towards Th2 responses, considered pathogenic in HIV infection. The other $\gamma$ chain cytokines have potentially beneficial effects to overcome immune dysfunction $[59,60]$.

IL-2 enhances both CD4 T cell proliferative and CD8 T cytolytic functions, but may also induce peripheral tolerance by activating regulatory $\mathrm{T}$ cells (Treg) [61]. Deficient IL-2 production upon antigenic stimulation has consistently been reported as a hallmark of HIV-related immune dysfunction, from the early 80 's on $[62,63]$. Interleukin-7 has been shown to play a crucial role in promoting expansion and maintenance of T cells. IL-7 production is increased during HIV-induced lymphopenia, but this feedback is apparently not sufficient to maintain $\mathrm{T}$ cell homeostasis [64]. The primary role of IL-15 is to expand the effector-memory subset of CD8 T cells, which is crucial in immune control, and to promote survival of NK cells. Several studies have shown that IL-15 production is compromised in AIDS patients, and supplementation of IL-15 improves the function of immune cells from these patients in vitro [65]. Finally, IL-21 promotes proliferation and accumulation of antigen-specific CD8 effector T cells, increases their survival and cytolytic potential, especially in synergy with other cytokines, and promotes differentiation of naive CD4 T cells without inducing Treg. IL-21 production is compromised early on during HIV infection and it is only partly restored by HAART [66].

Therapeutic use of interleukin-2 A number of smaller studies in the 90's evaluated systemic IL-2 therapy in HIV patients treated with mono- or dual- NRTI drug therapy. A pooled analysis suggested that this type of immunotherapy resulted in higher CD4 T counts, lower $\mathrm{VL}$, as well as fewer opportunistic infections and deaths [37]. In order to confirm the observed effects in fully treated patients, two multicenter placebo controlled trials with IL-2 were initiated. In both the SILCAAT and the ESPRIT trial, "induction" and "maintenance" cycles of sc IL-2 were added to virus-suppressive HAART. In both trials a positive effect on peripheral CD4 T counts was confirmed (temporary in ESPRIT and sustained in SILCAAT). VL was continuously suppressed (by HAART), but the occurrence of opportunistic infections or death was not altered as compared to HAART only [38]. Two smaller ANRS (Agence de Recherche sur le SIDA) studies addressed additional questions. ANRS 119 showed that intermittent IL-2 therapy in HAART-naïve patients with CD4 $\mathrm{T}$ counts between $300-500$ cells $/ \mathrm{mm}^{3}$ could induce a significant and sustained increase in CD4 $\mathrm{T}$ cells, though unfortunately without affecting VL, but, based on CD4 T criteria, initiation of HAART could be deferred [39]. The ANRS-NIH ILIADE trial suggested that administration of 3 cycles of IL-2 in HIV-infected 
patients with high CD4 T cell counts and controlled VL on HAART, could allow a significant delay in HAART resumption following treatment interruption [40]. Taken together, the potential beneficial effects of systemic IL-2 are rather limited; additionally, it is not devoid of side effects, and sc administration is cumbersome. Therefore, adjunctive systemic IL-2 therapy has not been adopted in routine clinical care. This negative appreciation, however, does not preclude a local targeted IL-2 administration in conjunction with therapeutic vaccination.

Therapeutic use of interleukin 7 A single injection of IL-7 in untreated HIV-infected subjects increased the number of circulating CD4 and CD8 T cells, mainly those of the central-memory type, without affecting the frequency of Tregs, but with a slight increase of viral RNA (blip) in half of the patients [41,42]. A prospective open label trial (EudraCT) investigated the effect of repeated sc IL-7 administration in those patients who remained lymphopenic under fully virus-suppressive HAART. A significant expansion of circulating memory, but also naive, CD4 and CD8 T cells was observed, without tolerability problems and without increases in $\mathrm{T}$ cell activation or proviral load. Moreover, IL-7 treatment counteracted IFN- $\alpha$ therapy-induced lymphopenia and stimulated SIV-specific cytotoxic $\mathrm{T}$ lymphocyte responses in SIV-infected rhesus macaques [43]. Ongoing phase 3 trials should indicate whether IL-7 has a role in correcting lymphopenia in patients who fail to recover CD4 $\mathrm{T}$ cell counts under HAART (or in purging the viral reservoir, as discussed above).

Therapeutic use of interleukin 15 Interleukin-15 has several theoretical advantages over IL-2, in that it inhibits apoptosis and enhances expansion of both CD4 and CD8 memory T cells, as well as NK cells [67]. However, systemic IL-15 administration in chronically SIV infected macaques treated with HAART resulted in a delay in viral suppression; and, when HAART was interrupted, IL-15 co-treated animals experienced a more rapid loss of CD4 T cells as compared to HAART-only treated animals [44]. These negative results have discouraged further systemic administration, though IL-15 might still be useful in conjunction with a HIV vaccine [68].

Therapeutic use of interleukin 21 Interleukin-21 might be the most suitable $\gamma$-chain cytokine for immunotherapeutic purposes. IL-21 by itself induced potent antiviral activity in human CD8 T cells [69] and augmented the lytic potential of NK and CD8 T cells from HIVinfected subjects [70-72]. HIV-1 specific IL-21 producing $\mathrm{CD} 4 \mathrm{~T}$ cell responses also contributed to durable viral control through the modulation of HIV-specific CD8 T cell function [73]. The in vivo relevance of all these in vitro/ex vivo observations was most recently confirmed in a small trial of systemic IL-21 administration in chronically untreated SIV infected rhesus macaques. IL-21 administration was well tolerated, augmented the cytotoxic potential of both T cells and NK cells, and promoted B cell differentiation with increased SIV antibody production, without an increase in cellular activation or plasma VL [45]. These results encourage further testing of IL-21 in conjunction with HAART and/or a specific therapeutic vaccine.

Blocking negative regulatory receptors In an elegant in vitro study, Shankar et al. recently showed that coculture of HIV-infected DC with naïve T cells induced elevated membrane expression of a broad array of negative costimulatory molecules such as PD-1 and CTLA-4, with a concomitant decreased expression of the effector cytokines [74]. Many of these characteristics of T cell anergy and exhaustion have also been described in $\mathrm{T}$ cells from HIV-infected subjects.

High levels of PD-1 were shown on both CD4 and CD8 T cells but particularly on HIV-1 specific cytolytic T cells (CTL), and were correlated with CTL dysfunction and apoptosis. PD-1 expression correlated directly with $\mathrm{VL}$ and disease progression and inversely with CD4 $\mathrm{T}$ counts. The natural ligand PD-L1 was significantly upregulated on antigen-presenting cells (APC) from HIVinfected individuals. Importantly, antibody-mediated blocking of this interaction improved HIV-specific T cell functions in vitro $[75,76]$.

CTLA-4 is overexpressed on CD4 T but not on CD8 $\mathrm{T}$ cells and more particularly on HIV-specific $\mathrm{T}$ cells in all infected subjects, except elite controllers. In vitro blocking of CTLA-4 augmented HIV-specific CD4 T cell proliferation. Additionally, CTLA-4 signaling resulted in high CCR5 expression and enhanced susceptibility to viral infection [75].

\section{Contrasting effects of therapeutic blocking of PD-1} and CTLA-4 Administration of blocking antibodies to PD-1 during chronic SIV infection in macaques had remarkably positive effects. A rapid expansion of virusspecific CD8 T cells with improved functional quality, as well as B cell activation with increased SIV-specific antibodies was observed. These immune phenomena were associated with significantly reduced plasma VL and prolonged survival [46]. Interestingly, PD1 blocking actually reduced immune hyper-activation, expression of type 1 IFN stimulated genes (ISG) and bacterial translocation, and enhanced immunity to gut-associated pathogens [77].

The results of CTLA-4 blocking in this primate model were unfortunately less encouraging. Whereas an increase in $\mathrm{CD} 4$ and $\mathrm{CD} 8 \mathrm{~T}$ responses and a decrease of 
viral RNA in lymph nodes were noted in an early study [47], the second trial showed no expansion of SIVspecific CTL, but an increased activation of CD4 T cells and viral replication at mucosal sites [48]. These discrepant results may point to the delicate balance of enhancing beneficial HIV-specific responses and increasing deleterious immune activation.

Clearly, blocking various individual and combined negative receptors should be studied in more detail in SIV-infected animals; additionally, the potential synergy of receptor blocking with therapeutic vaccines and other anti-retroviral therapies should be investigated.

\section{HIV-antigen specific immune therapies}

A general overview is presented in Figure 1 and Table 2.

\section{Remune $^{\circledR}$}

Remune $^{\circledR}$ was derived from a Congolese clade A/G HIV-1, which was gp120 depleted, chemically inactivated, irradiated, and emulsified with incomplete Freund's adjuvant [112]. The first uncontrolled clinical trials all showed that Remune ${ }^{\circledR}$ induced HIV-specific T cell responses [78]. In an open Remune ${ }^{\circledR}$ trial in chronically infected subjects, with suboptimal drug treatment, a significant delay in viral rebound after treatment interruption (TI) was observed [78]. Another open trial in asymptomatic non-treated HIV-infected individuals reported higher CD4 and CD8 T-cell counts and stable VL [79]. However, these beneficial effects were not observed in a randomized, double-blind, placebocontrolled study with patients, receiving full HAART during acute infection and vaccinated with either placebo, ALVAC (canarypox expressing env, gag, pol and nef - see below) or with ALVAC + Remune ${ }^{\circledR}$. After analytical treatment interruption (ATI), there was no difference in viral rebound between the three arms [80].

\section{Plasmid DNA vaccination}

DNA-based vaccines have the conceptual advantage over other vaccines in that they can express both viral antigens and "molecular adjuvants", such as cytokines or costimulatory molecules. Moreover, they can be administered repeatedly without inducing anti-vector immunity. DNA vaccines have successfully been used prophylactically in various infectious models in rodents, but they are less efficient in primates. Nevertheless, repeated intramuscular (im) immunization with carefully designed optimized SIVmac239 gag and env plasmids by Pavlakis' group resulted in strong cellular and humoral responses in naïve Indian rhesus macaques and a significant sustained reduction of VL upon mucosal infection with the related SIVmac251 [81]. This DNA vaccine was

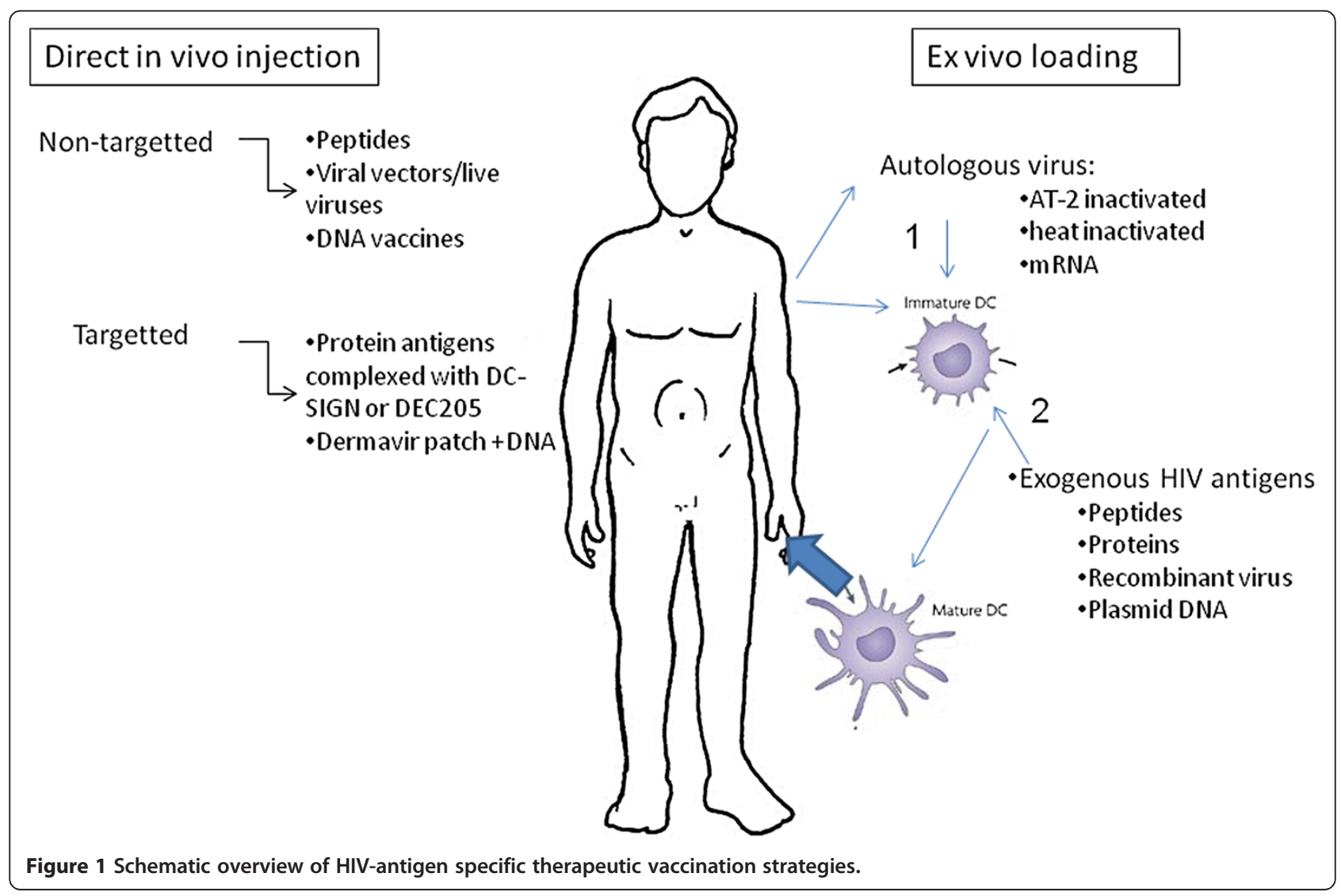


Table 2 HIV-antigen specific therapeutic vaccinations

\begin{tabular}{|c|c|c|c|c|c|c|c|}
\hline \multicolumn{8}{|c|}{ a) Non dendritic cell-based } \\
\hline Name Trial & Species & $\begin{array}{l}\text { Baseline patients } \\
\text { characteristics }\end{array}$ & Type of immune therapy & $\begin{array}{l}\text { Route and frequency of } \\
\text { administration }\end{array}$ & $\begin{array}{l}\text { Number of } \\
\text { patients }\end{array}$ & Outcome & References \\
\hline $\begin{array}{l}\text { Uncontrolled } \\
\text { clinical trial }\end{array}$ & Human & Therapy naïve & Remune $^{\circledR}$ & iv & 2527 & $\begin{array}{l}\text { Increased HIV-specific T cell responses. } \\
\text { Positive impact on controlling the virus. }\end{array}$ & [78] \\
\hline $\begin{array}{l}\text { P2101B (thai open } \\
\text { label trial) }\end{array}$ & Human & Therapy naïve & Remune $^{\circledR}$ & $\begin{array}{l}\text { iv every } 12 \text { weeks for } \\
132 \text { weeks }\end{array}$ & 223 & $\begin{array}{l}\text { Increasing CD4 and CD8 T cell counts } \\
\text { and stable viral load. }\end{array}$ & [79] \\
\hline $\begin{array}{l}\text { Randomized double } \\
\text { blind placebo } \\
\text { controlled trial }\end{array}$ & Human & HAART & $\begin{array}{l}\text { ALVAC, ALVAC + Remune, } \\
\text { placebo }\end{array}$ & $\begin{array}{l}\text { iv injections Alvac @w 8, } \\
\text { 12, 16,20. Remune@w } \\
0,4,12,20\end{array}$ & 79 & $\begin{array}{l}\text { Safe and immunogenic. No difference } \\
\text { between the three groups after STI } \\
\text { on viral rebound. }\end{array}$ & [80] \\
\hline \multirow[t]{3}{*}{ Placebo controlled } & $\begin{array}{l}\text { Indian rhesus } \\
\text { macaque }\end{array}$ & Chronic SIV HAART & $\begin{array}{l}\text { SIV mac } 239 \text { gag and env } \\
\text { DNA vaccine }\end{array}$ & im 3 injections & 23 & $\begin{array}{l}\text { Increase in HIV specific cellular } \\
\text { responses and lower viral rebound } \\
\text { in vaccinated animals. }\end{array}$ & [81] \\
\hline & $\begin{array}{l}\text { Indian rhesus } \\
\text { macaque }\end{array}$ & Chronic SIV HAART & $\begin{array}{l}\text { SIV mac } 239 \text { gag and env } \\
\text { DNA vaccine }+ \text { IL-15 }\end{array}$ & In vivo electroporation & 3 & $\begin{array}{l}\text { Sustained polyfunctional T cells. } \\
\text { One log decrease in VL. }\end{array}$ & [82] \\
\hline & Human & HAART & $\begin{array}{l}\text { DNA vaccine consisting of } \\
\text { CTL epitopes }\end{array}$ & im injections w 0, 4, 8, 16 & 41 & $\begin{array}{l}\text { Safe and tolerable. In some persons } \\
\text { weak responses. Overall no differences } \\
\text { with placebo group. }\end{array}$ & [83] \\
\hline \multirow[t]{2}{*}{$\begin{array}{l}\text { VRC HIV DNA 009-00-VP } \\
\text { double blind placebo } \\
\text { controlled }\end{array}$} & Human & HAART & $\begin{array}{l}\text { plasmid DNA encoding } \\
\text { subtype B Gag-Pol-Nef } \\
\text { and multiclade env }\end{array}$ & im injections w 0, 4, 8, 24 & 20 & $\begin{array}{l}\text { Poorly immunogenic. No effect on } \\
\text { viral rebound after ATI. }\end{array}$ & [84] \\
\hline & Human & HAART & Plasmid DNA multiclade & Patch & 12 & $\begin{array}{l}\text { Broader and higher HIV specific T-cell } \\
\text { responses. No effect on viral rebound } \\
\text { after ATI. }\end{array}$ & {$[85]$} \\
\hline $\begin{array}{l}\text { ANRS } 094 \text { single } \\
\text { arm open }\end{array}$ & Human & & ALVAC VCP1433 & im injections w 0, 4, 8, 12 & 50 & $\begin{array}{l}\text { Safe and immunogenic. Delay in } \\
\text { treatment resumption of ATI. }\end{array}$ & [86] \\
\hline ANRS 093 & human & HAART & $\begin{array}{l}\text { ALVAC + lipo } 6 \text { T } 4 \text { injections } \\
\text { followed by } 3 \text { cycles sc IL2 }\end{array}$ & $\begin{array}{l}\text { im injections of ALVAC w } 0 \text {, } \\
4,8,12 \text {. IL-2@w 16, 24, } 32\end{array}$ & 71 & $\begin{array}{l}\text { Lower viral set point after ATI, correlated } \\
\text { with HIV specific CD4 T cell responses. }\end{array}$ & {$[87]$} \\
\hline $\begin{array}{l}\text { ACTG (A5024) } \\
\text { randomized partially } \\
\text { blinded phase ॥ }\end{array}$ & Human & HAART & $\begin{array}{l}\text { ALVAC ALVAC + sC IL2 SC IL2 } \\
\text { alone placebo }\end{array}$ & $\begin{array}{l}\text { im injections of ALVAC } w \text {, } \\
4,8,12 \text {. IL-2 sc for } 5 \text { days in } \\
8 \text { week cycles }\end{array}$ & 19 & $\begin{array}{l}\text { Lower viral rebound after ATI in ALVAC } \\
\text { vaccines. IL-2 + vaccine boosted CD4 T cell } \\
\text { count but had no influence on VL. }\end{array}$ & [88] \\
\hline $\begin{array}{l}\text { Double blind } \\
\text { placebo controlled }\end{array}$ & Human & $\begin{array}{l}\text { HAART (acute } \\
\text { phase) }\end{array}$ & ALVAC ALVAC + Remune & $\begin{array}{l}\text { iv injection of ALVAC w8, } 12 \text {, } \\
16,20 \text {. remune } w 0,4,12,20\end{array}$ & 79 & $\begin{array}{l}\text { No influence on VL after ATI. Increased } \\
\text { CD4 and CD8 T cell responses }\end{array}$ & [80] \\
\hline $\begin{array}{l}\text { CTN173 randomized } \\
\text { controlled }\end{array}$ & Human & HAART & $\begin{array}{l}\text { ALVAC, ALVAC + remune, } \\
\text { placebo }\end{array}$ & $\begin{array}{l}\text { im injections of ALVAC w8, } \\
\text { 12, 16, 20. Remune w0, 12, } \\
\text { 20. ATI w24 }\end{array}$ & 52 & $\begin{array}{l}\text { No lower viral setpoint. Tendency } \\
\text { towards delay of rebound }\end{array}$ & [89] \\
\hline \multirow[t]{3}{*}{ ORVACS } & Human & HAART & ALVAC vcp1420 placebo & im injections w 0, 4, 8, 20 & 65 & Higher viral rebound in vaccines & {$[90]$} \\
\hline & \multirow[t]{2}{*}{ Human } & \multirow[t]{2}{*}{ HAART } & Fowlpox gag/pol (PC) & \multirow{2}{*}{$\begin{array}{l}3 \text { im injections (w 0,4, 12). } \\
\text { ATI w20 }\end{array}$} & \multirow[t]{2}{*}{35} & \multirow{2}{*}{$\begin{array}{l}\text { Lower man viral rebound in FC group } \\
\text { and this is associated with lgG2 antibodies } \\
\text { to HIVp24 }\end{array}$} & \multirow[t]{2}{*}[91,92]{} \\
\hline & & & Fowlpox gag/pol IFN-y (FC & & & & \\
\hline
\end{tabular}


Table 2 HIV-antigen specific therapeutic vaccinations (Continued)

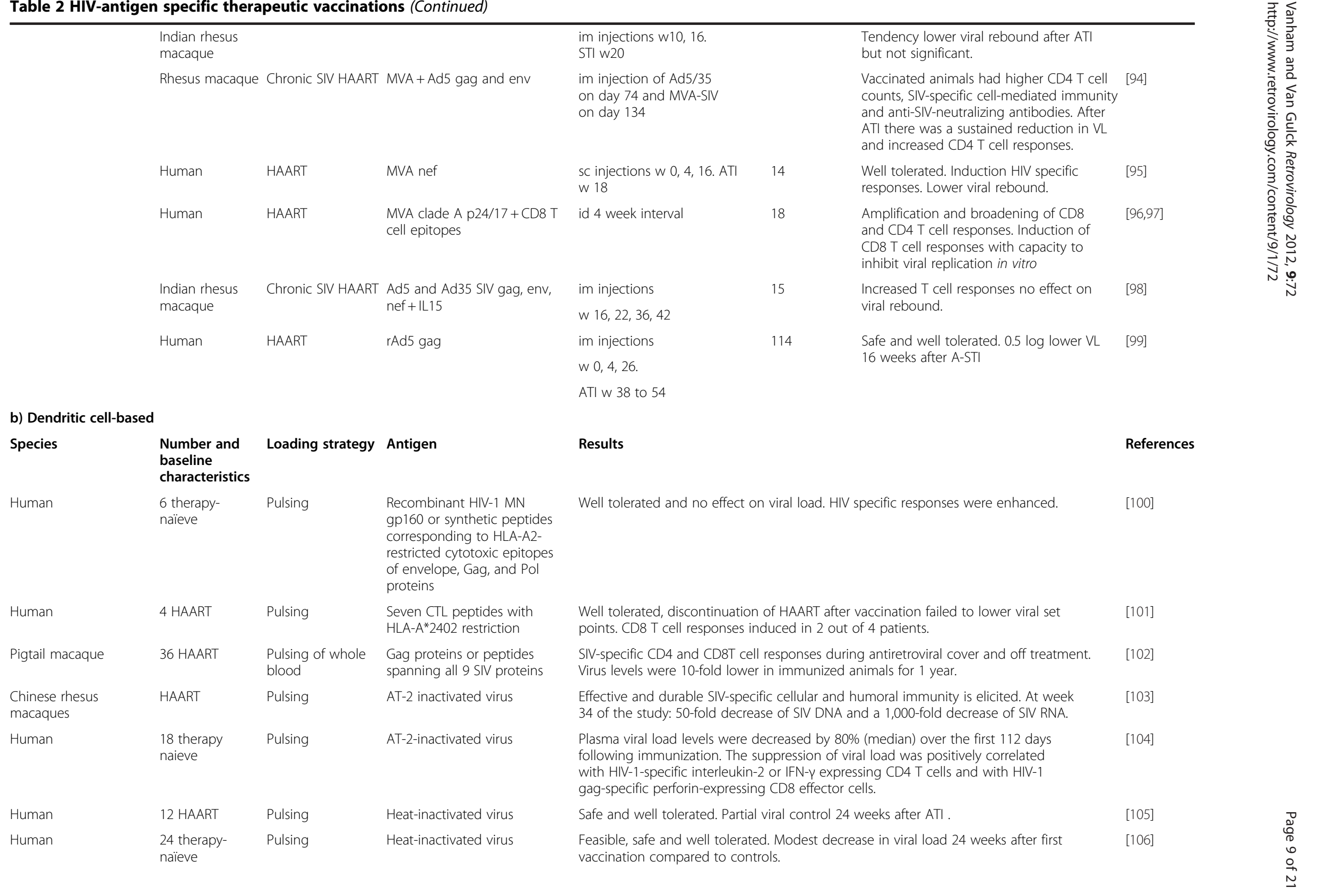


Table 2 HIV-antigen specific therapeutic vaccinations (Continued)

Human 29 HAART Live virus ALVACvcp1452

ALVACVcP $1452+$ KLH

$\mathrm{KLH}$

$\begin{array}{lll}\text { Human } & 9 \text { HAART } & \text { Electroporatio } \\ \text { Human } & 9 \text { HAART } & \text { Electroporatio } \\ \text { Human } & 17 \text { HAART } & \text { Electroporatio } \\ \text { Human } & 6 \text { HAART } & \text { Electroporatio }\end{array}$

Autologous mRNA encoding Gag, Vpr, Rev and Nef

Autologous mRNA encoding Partial viral control.

Gag, Vpr, Rev and Nef

mRNA encoding tat rev nef

mRNA encoding gag and

mRNA encoding tat rev nef

Viral load rebounded in both groups no differences in HIV-specific immune responses.

$[107]$ 
further improved by adding a plasmid encoding Nef-TatVif (NTV) fusion protein and applying in vivo electroporation [82].

The same group of researchers next used this strategy in a therapeutic setting, comparing HAART alone or HAART + 3 DNA vaccinations in chronically SIV-infected animals. A significant increase in cellular responses was noted in the vaccinated animals. Upon ATI, the HAARTonly treated animals showed a full-blown viral rebound and gradually progressed to AIDS, whereas only a limited viral rebound was observed in the vaccinated animals and a 10 times lower VL was sustained for 3 years [113]. At that time, the combination of HAART and therapeutic DNA vaccine was repeated in some of the originally vaccinated animals, using an improved strategy with a DNA construct, containing the 5 SIV genes + IL-15+ IL-15 receptor $\alpha$ genes, and using in vivo electroporation. This repeated vaccination resulted in sustained polyfunctional central memory and effector memory CD4 and CD8 T cell responses and, importantly, an additional 1 log reduction in VL load after ATI [114]. These studies therefore provide proof-of-principle for plasmid DNA as a therapeutic vaccine.

However, in HAART-treated HIV-infected subjects the evidence for success of DNA vaccination has not yet been delivered. Repeated im injections of a DNA vaccine, based on CTL epitopes from multiple HIV-1 gene products elicited only weak $\mathrm{T}$ cell responses in HAART treated chronic patients [83]. The VRC-HIVDNA 00900-VP, consisting of 4 plasmids encoding a subtype B Gag-Pol-Nef fusion protein and modified multiclade envelope constructs, was tested in a double blind placebo controlled study on patients treated with HAART during the acute/early phase. Even four im injections remained poorly immunogenic, and there was no effect on viral rebound after ATI [84]. A similar study in chronically treated patients, using DNA plasmids containing genes of several HIV-1 subtypes, apparently resulted in broader and higher HIV-specific T cell responses, but again there was no favorable effect on the viral rebound after ATI [85]. The DermaVir concept, recently reviewed by Lori, features a single plasmid DNA expressing 15 HIV antigens, a nano-particular formulation and a dendritic cell (DC) targeting topical (skin patch) administration. An impressive amount of safety and immunogenicity studies has been accumulated, but no statistically convincing data on VL reduction have been presented yet $[115,116]$.

In a preventive setting, co-delivery of the genetic information to produce IFN- $\gamma$, IL-12, IL-15 or IL-18 has been shown to enhance $T$ cell responses to SIV or HIV DNA constructs in non-infected macaques [117]. A favorable immune enhancement effect of co-delivered IL-12 or IL15 genetic information was confirmed in a therapeutic setting in SIV-infected macaques [118] as well as in HIV-infected chimpanzees [119]. A strong synergistic effect between IL-12 and in vivo electroporation was also observed in preventive DNA vaccination in macaques [120]. In a human preventive setting, however, coadministration of IL-12 and/or IL-15 plasmids im failed to enhance $\mathrm{T}$ cell responses to HIV-1 gag DNA vaccine [121]. In vivo electroporation might be a viable option in humans, as two recent studies in healthy volunteers confirm the afore mentioned macaque data in that the $\mathrm{T}$ cell responses to intradermally (id) applied plasmid HIV DNA, followed by in vivo electroporation, are much stronger and more polyfunctional than those induced by regular im injection without electroporation $[122,123]$.

\section{Viral vectors expressing HIV antigens}

Canarypox vector (ALVAC) ALVAC is a recombinant canarypox vaccine, expressing full length env and gag as well as portions of pol and nef. The vCP1521 variant, expressing subtype E gp120 and gp41, gag and protease of subtype B, was used as a prime for AIDSVAX (VaxGen bivalent gp120 subtype B/E), the recombinant glycoprotein boost in the prophylactic RV144 "Thai" trial, which showed a $31.2 \%$ protective efficacy against HIV acquisition [124]. The mechanisms of this protection are still under active investigation.

ALVAC vCP1433 and vCP1452, based on subtype B LAI sequences have been used in several therapeutic settings with varying success. The open-label single arm ANRS 094 study used 4 monthly im ALVAC injections, showing safety and immunogenicity [86]. The ANRS 093 trial used 4 im injections of ALVAC and Lipo-6T, a mixture of HIV derived lipopeptides, followed by 3 sc cycles of IL-2 in chronic HIV patients under stable HAART and included a control group under HAART alone. After ATI, a larger proportion of subjects in the vaccine group managed to lower their viral setpoint ( $24 \%$ vs $5 \%$ ), and this was correlated with an enhanced vaccine-induced CD4 $\mathrm{T}$ cell response [87]. A follow-up study in HAART patients (ACTG A5024) included 4 arms, comparing placebo with ALVAC-HIV alone, sc IL-2 + ALVAC placebo, and the combination ALVAC-HIV and IL-2. Viral rebound, assessed 12 weeks after ATI, was 0.5 logs lower in both ALVAC-HIV vaccinated groups, whereas IL-2 increased CD4 $\mathrm{T}$ counts but did not diminish VL [88]. These early studies suggest that ALVAC vaccination can partly prevent viral rebound in chronically infected HAART patients.

As mentioned, a double blind placebo controlled trial with ALVAC-HIV or ALVAC-HIV and Remune ${ }^{\circledR}$ in patients already treated in the acute phase (QUEST), confirmed induction of immune responses, but did not result in better virological control 24 weeks after 
interruption of HAART [80]. A very similar study in chronic patients (CTN173) confirmed that both vaccines were unable to lower the viral setpoint, but nevertheless tended to delay rebound and extend time to restart HAART, which was also marginally correlated with higher IFN- $\gamma$ and IL-2 responses [89].

Finally, a rather disappointing result was obtained in the ORVACS study, where 4 and 3 injections of ALVAC vCP1452 were compared with placebo in chronic HAART patients. The vaccines were immunogenic, but both vaccinated groups showed a higher viral rebound and had to resume treatment more rapidly than the placebo group [90]. A lower CD4 nadir and a higher vaccine-induced HIV-specific CD4 $\mathrm{T}$ cell cytokine response in Enzyme Linked Immunosorbent Spot Assay (ELISPOT) were predictive of this adverse outcome [125]. This result is somehow reminiscent of the prophylactic STEP trail, where vaccine-induced $\mathrm{CD} 4 \mathrm{~T}$ cell activation has been invoked to explain apparently enhanced susceptibility to HIV infection [126].

Clearly, these various ALVAC trials provided rather contradictory results. Nevertheless, they indicate that baseline characteristics of patients (e.g. pre-treatment VL or CD4 T cell nadir) need to be carefully matched, and they confirm the notion that vaccine-induced immune activation can have both beneficial and adverse effects: whereas HIV-specific $\mathrm{T}$ cell activation is required to control viral rebound, immune stimulation can also increase the susceptibility of $\mathrm{CD} 4+$ target cells to productive infection.

Fowl pox An Australian group compared two recombinant fowl pox vectors: one expressing gag/pol from subtype B only (a so-called partial construct or PC), while the second co-expressed human IFN- $\gamma$ (full construct or FC), in addition to a placebo (diluent only). Thirty five fully HAART-treated subjects were randomized to the 3 regimens (12 placebo -11 PC -12 FC) and received $3 \mathrm{im}$ injections (week 0,4 and 12), and were then followed up for 52 weeks under HAART [91]. A subset (7 placebo; $8 \mathrm{PC}$ and $10 \mathrm{FC}$ subjected) underwent ATI for 20 weeks thereafter [92]. The most remarkable observation was a significantly lower mean viral rebound in the FC patients $(+0.96 \mathrm{log})$, as compared to placebo $(+1.80 \mathrm{log})$ and $\mathrm{PC}(+1.78 \mathrm{log})$. The $\mathrm{T}$ cell responses during the vaccination period were very weak. During ATI the IFN- $\gamma$ ELISPOT increased in all three groups, but the changes were higher in the placebo as compared to the vaccinated patients. In a post hoc analysis, however, it was found that IgG2 antibodies to HIV p24 were present at 52 weeks (time of ATI start) in 5/9 FC patients and not in the PC or placebo patients. The presence of these antibodies was associated with lower viral rebound [127]. Clearly, the addition of IFN- $\gamma$ to the vaccine seemed to be beneficial, and IgG2 antibodies were implicated in this protective effect.

Modified Vaccinia Ankara (MVA) Several constructs expressing various HIV or SIV genes in replicationdeficient poxvirus have been used as prophylactic vaccines in macaques, preceded by plasmid DNA priming with the same antigens. Partial, but sustained, protection has repeatedly been shown against homologous challenges: in most cases infection could not be prevented, but VL was lower and disease progression delayed or halted [128-130]. Whereas correlations with neutralizing antibodies as well as CD4 and CD8 $\mathrm{T}$ cell responses were noted in some cases, a crucial role for CD8 T cells in this protection was strongly suggested by a CD8 depletion approach in the study of Amara [131].

A few studies addressed the potential therapeutic effect of MVA expressing SIV antigens in infected macaques under antiretroviral treatment. A small trial using MVA gag-pol/MVA env or MVA tat-ref-nef in SIVinfected animals, treated with the NRTI PMPA, showed a tendency towards lower viral rebound after ATI in the vaccinated groups [93]. A regimen with combined Adenovirus constructs (see below) and MVA expressing gag and env in infected and treated macaques provided a more sustained reduction in VL and increase of CD4 T cell counts, correlated with increased anti-SIV cellmediated and humoral responses [94].

In HIV-infected subjects under HAART, nef-expressing MVA was shown to induce CD8 and CD4 T cell responses in some patients and there was a relatively lower viral rebound after treatment interruption [95]. An elegant series of studies was carried out in 16 chronically infected patients under HAART, using an MVA construct expressing consensus clade A p24/p17 and multiple CD8 $\mathrm{T}$ cell epitopes. The authors showed that both CD4 and CD8 $\mathrm{T}$ cell responses were amplified and broadened, and that CD8 T cells acquired the capacity to inhibit HIV-1 replication in vitro $[96,97]$. Especially the latter characteristic seems most important for potential therapeutic effect.

Other groups have also developed promising HIV MVA constructs that elicited polyfunctional CD4 and CD8 T cell responses in either healthy or HIV infected subjects [132-134], and more formal testing in therapeutic trials is presumably ongoing.

Adenovirus constructs Two phase IIb studies, STEP and Phambili, evaluated the prophylactic effect of the replication- defective recombinant adenovirus type 5 (rAd5) MRK gag/pol/nef vaccines in healthy volunteers. Clearly, neither trial showed a decrease in HIV acquisition, nor decreased early plasma VL in vaccinees, who were infected. A post-hoc analysis showed even an 
increased risk of infection in uncircumcised vaccinated men, who were already Ad5 seropositive before vaccination [135]. This deleterious effect was tentatively explained by the observation that Ad5 could induce expansion of memory CD4 T cells with a mucosal homing phenotype, which are readily susceptible to HIV-1. Several studies provided evidence that the untoward effect of pre-existing Adeno immunity by natural infection could have a negative impact on immune responses against HIV and could increase susceptibility towards HIV infection, even if rare Adeno serotypes were being used $[126,136,137]$.

Human replication deficient rAd5 and rAd35 vectors, encoding SIV gag, env and nef (with or without IL-15 encoding cassettes), were used in chronically SIVmac251 infected and properly treated macaques, followed by ATI. HIV specific T cells were increased but viral rebound was not influenced [98].

The AIDS Clinical Trial Group (ACTG) protocol A5197 was a randomized placebo controlled trial to test rAd5 expressing gag in chronically infected patients under stable HAART with 77 persons in the vaccinated and 37 in the placebo group. Interestingly, 16 weeks after ATI, the plasma VL was 0.5 logs lower in the vaccinated group [99].

Though the therapeutic trial in SIV-infected macaques was not promising, the rather positive result of the ACTG trial in chronic HAART patients raises some hope. There are several recent studies in seronegative controls indicating that a prime-boost regimen with HIV env and gag/pol DNA/Ad5 may enhance antibody titers and $\mathrm{T}$ cell responses. Importantly, the $\mathrm{T}$ cells showed not only increased poly-functionality, but also a significant HIVsuppressive effect towards several HIV strains, including transmitted/founder viruses in vitro $[138,139]$. Another possible way forward is the subsequent vaccination with rAD5 and rMVA, with synergistic activities on effector memory and central memory CD8 T cells [140].

\section{Dendritic cell based immunotherapy}

A number of DC-based therapeutic trials have recently been completed in animals and humans. DC have the capacity to process proteins through both MHC class I and class II pathways for stimulation of CD8 or CD4 T cells respectively. Antigen can be provided to DC in many formats: as peptides, whole proteins or apoptotic cells, and also in a "genetic" format by transfecting DC with antigen-encoding viral vectors in DNA or mRNA format.

\section{a) Antigenic peptides and recombinant proteins}

The use of antigenic peptides is an efficient loading strategy, but DC can also be pulsed with recombinant HIV proteins [24]. In principle, "exogenous" protein should preferentially induce MHC (HLA)-class II restricted CD4 T cells, whereas peptides could stimulate both CD4 and CD8 T cells, according to their class I or II binding, depending on their length and composition. The first small trial in humans was performed by Kundu and showed that the administration of HIV peptides or protein-pulsed autologous DC was well-tolerated and could enhance the immune response to HIV in therapy-naïve patients with normal CD4 T cell counts [100]. In a second trial, 6 doses of synthetic HIV-1 peptidepulsed autologous DC were administered to 4 HAART-treated, HLA-A2402 individuals who underwent ATI: no significant changes in VL or CD4 T cells were observed during ATI [101]. Finally, De Rose et al. performed an intriguing trial in pigtail macaques, where blood was exposed ex vivo to overlapping SIV peptides or medium for 1 hour and re-injected. This procedure was repeated 7 times. SIV specific CD4 and CD8 T cell responses were induced; and, remarkably, virus levels were approximately 10-fold lower for 1 year in immunized animals as compared to medium controls [102]. A basic problem with peptides and proteins, however, is that it is difficult to cover HIV variability and HLA polymorphisms at an affordable cost.

b) Whole inactivated virus

Whole inactivated HIV-1 particles have successfully been used in DC vaccination of mice, monkeys and humans. Two prophylactic trials were performed in severe combined immunodeficient (SCID) mice, reconstituted with human PBMC. Yoshida and colleagues used IL-4 DC (i.e. monocytes differentiated into DC in the presence of IL- 4 and GM-CSF and matured with IFN- $\alpha$ ), whereas Lapenta and colleagues used IFN-DC (i.e. monocytes differentiated into DC in the presence of IFN- $\alpha$ and IL-4). In both trials, autologous DC were pulsed with aldrithiol (AT)-2-inactivated R5 subtype B viruses: HIV-1 ${ }_{\text {SF-162 }}$ by Lapenta [141] and HIV-1 $1_{\text {JR-CSF }}$ by Yoshida [142]. After vaccination with the pulsed DC, HIV-1 specific CD4 and CD8 T cells were generated in vivo. Moreover, upon infection with homologous virus, there was also evidence for partial protection. Around the same time, Lu et al. published their paper on therapeutic vaccination in Chinese rhesus macaques [103]. They used AT-2-inactivated SIVmac251-pulsed IL-4 DC, matured with the classical "Jonuleit" cytokine cocktail, consisting of IL$1 \beta$, tumor necrosis factor- $\alpha$, IL- 6 and Prostaglandin $\mathrm{E}_{2}$ [143]. All animals displayed a significant decrease in viral load 10 days after vaccination and an increased CD4 T cell count. Clearly enhanced SIVspecific cellular immunity was also observed. 
The same authors vaccinated 18 untreated chronically HIV-infected patients, using IL-4 DC pulsed with autologous AT-2-inactivated virus. This resulted in an effective HIV-1-specific T cell response with sustained viral suppression of over $90 \%$ in 8 of 18 subjects [104]. Based on statistical correlations, robust virus-specific $\mathrm{CD} 4 \mathrm{~T}$ helper cells were required to induce and maintain virus-specific CD8 $\mathrm{T}$ effector cells for virus containment.

In another clinical trial, Garcia used heat-inactivated autologous virus to pulse IL-4 DC: in 12 HIV-1infected persons under HAART, partial viral control could be achieved 24 weeks after ATI [105]. In contrast to the observations of Lu et al., the HIVspecific cellular immune response was weak and transient in Garcia's study. The latter author also performed a double blind clinical trial on untreated HIV-1 infected patients with IL4 DC pulsed with heat-inactivated virus [106]. VL in the active group was maintained at a lower level as compared to the placebo group at week 48 . However, this result was inversely correlated with HIV-1 specific immune responses.

Clearly, although Lu's and Garcia's vaccination strategies both yielded a positive effect on VL, the association between $\mathrm{VL}$ and $\mathrm{T}$ cell responses was different. Whether this discrepancy is due to the different inactivation procedure (AT2 vs. heat inactivation) or other factors remains to be investigated.

Unfortunately, DC loading with inactivated virus is difficult to standardize due to numerous variables: type and activation state of infected cells, method of virus inactivation, and the amount of antigen in the preparation. Moreover, it requires meticulous quality control testing on the inactivation procedure in order to eliminate any biological risk of infection.

c) Live viral vectors

As already discussed, direct vaccination with Canarypox virus vectors carrying HIV-1 genes (ALVAC) yielded discordant results in several studies. Recently a phase I/II clinical trial was performed, comparing direct injection of ALVAC vCP1452 and keyhole limpet hemocyanin (KLH) as adjuvant with injection of autologous IL-4 DC infected ex vivo with ALVAC VCP1452 and treated with KLH. After three injections, subjects underwent a minimum of a 12-week ATI. Viral load rebounded in both groups and there was also no difference in HIV specific responses [107].

d) $m R N A$ and DNA

Loading HIV antigens encoded by nucleic acid, either cDNA or mRNA, is easier to standardize, it does not carry infectious risk, and hence seems straightforward for clinical applications. In our hands, transfection of IL-4 DC with cDNA is less attractive than mRNA, as cDNA electroporation resulted in more cell death and expression levels were lower, probably due to the more stringent transformation conditions required to penetrate into the nucleus. Transfection with mRNA encoding antigens requires cytoplasmic penetration only and was very efficient for loading DC and subsequent stimulation of HIV-specific T-cells [144].

Several clinical trials have already been performed based on DC electroporated with mRNA encoding HIV-1 proteins. In AGS-004, nine HAART-treated individuals were vaccinated with autologous IL-4 DC electroporated with mRNA encoding CD40L and autologous HIV antigens Gag, Vpr, Rev and Nef. Patients received monthly injections in combination with HAART [108]. Seven out of nine patients showed proliferative CD8 T cell responses. This vaccine was further evaluated in a phase II study, resulting in partial viral control [109]. Another recent clinical trial was performed by Allard et al. In this study, 17 HIV infected individuals on HAART received 4 vaccinations with 4 week intervals of autologous IL-4 DC electroporated with mRNA encoding a subtype B TatRevNef fusion protein. Four weeks after the last vaccination, treatment was interrupted [110]. Six out of 17 patients remained off therapy 69 weeks after ATI. However this clinical result was not better than a historic control group undergoing STI, despite the induction and enhancement of CD4 and CD8 T cell responses specific for the vaccine [110]. Around the same time our group also performed a phase I/II clinical trial: 6 HIV-infected individuals who received stable HAART were included. Individuals were vaccinated with autologous IL-4 DC electroporated with mRNA encoding the same TatRevNef fusion protein as in Allard's study and with IL-4 DC expressing subtype B Gag mRNA. After vaccination, HIV-specific responses to Gag were increased in magnitude, breadth and proliferative capacity. Although no virological parameters could be measured because patients did not undergo ATI, we showed that the CD8 T cells from the vaccines could inhibit superinfection of autologous CD4 T cells with vaccine related IIIB virus in vitro [111]. Overall, 210 patients (60 therapy naïve and 150 on HAART) have been recruited in clinical trials with DC based vaccines. The safety profile has been excellent and DC therapy clearly elicits HIV-1 specific immunological responses, but only four of these studies reported virological responses to immunization [145]. 
e) In vivo targeting of dendritic cells

Current immunotherapeutic strategies involve the ex vivo manipulation of autologous DC. This vaccination procedure is labor-intensive, logistically complicated, expensive and not useful in developing countries. A possible solution is direct in vivo delivery of suitable antigens and co-stimuli to resident DC. A first attempt in animal models was to apply protein antigens in complex with antibodies to DC-specific membrane molecules such as DC-SIGN or DEC-205 [146,147]. A future strategy could be the delivery of biodegradable nanoparticles, which will be taken up by endocytic DC in vivo, such as the DermaVir patches [115].

\section{Conclusions}

Early attempts of immunotherapy, during the preHAART era, included non-specific (e.g. IFN and IL-2) and HIV-specific (e.g. Remune) immune interventions in patients who were either untreated or received mono- or dual drug therapy. In some cases positive effects have been reported, but these trials were small and usually not well controlled. During the last 10-15 years, the concept of immunotherapy as a supplement to full HAART has been further developed, with the ultimate aim to reduce or even replace drug therapy.

Amongst the non-antigen-specific immune approaches, systemic IL-2 has been exhaustively investigated and was ultimately shown not to provide clinical benefit in addition to HAART. It remains to be seen whether systemic use of other common $\gamma$ chain cytokines, such as IL-7 or IL-21, could be useful for particular indications (e.g. to counteract lymphopenia). The newer "nonspecific" approach is to block negative regulatory pathways, such as PD-1 or CTLA-4 signaling, both overexpressed during HIV infection. Experimental treatment in SIV-infected macaques indicated that PD-1 blocking helped to control viremia and to reduce immune activation. In contrast, CTLA-4 blocking resulted in increased viremia, most probably as a result of an unfavorable balance between too much non-specific and insufficient specific immune activation.

The obvious goal of therapeutic vaccination is to stimulate effective HIV-specific T cell responses, primarily cytolytic/virus suppressive CD8 $\mathrm{T}$ cells with supporting CD4 T cell help, while avoiding increased HIVsusceptibility of target cells. To that end, protein or particulate antigen is conceptually not the best option, since it primarily results in $\mathrm{CD} 4 \mathrm{~T}$ and $\mathrm{B}$ cell activation: antibodies are considered ineffective and CD8 T cells seem essential in immune protection post infection.

Repeated im vaccination with plasmid DNA encoding various HIV antigens, along with cytokines, was successful in lowering VL in macaques, but this has not yet been confirmed in humans, despite repeated attempts. However, the immunogenicity of DNA vaccination is being improved by innovative constructs and enhanced delivery systems [148]. Especially for applications in less sophisticated environments, DNA vaccines have the advantage of being stable and to carrying no infectious risk, but because they are considered "genetic therapy", the development of DNA vaccines is subjected to strict regulations [149].

Recombinant viral vectors have been applied rather extensively in therapeutic vaccination trials. In most cases poxviruses (e.g. canary pox, fowl pox and MVA) and occasionally Adenoviruses were used. A fair number of encouraging results were observed in infected/treated macaques and patients in terms of $\mathrm{T}$ cell responses, and in some cases also VL reduction after ATI was observed. However, the variable results, obtained with the most extensively used canarypox platform, ALVAC, illustrate that apparently similar trials can have quite discrepant outcomes. Again, this may be the result of a delicate balance between the beneficial enhancement of anti-HIV CD8 $T$ cell immunity and the deleterious effect of nonspecific immune activation, inducing increased cellular susceptibility to HIV infection.

DC-based therapy has been developed in a therapeutic context, with various antigenic formats and corresponding loading strategies. Remarkably positive results in terms of viral control have been obtained with autologous inactivated virus loaded DC. DC trials with safer and less cumbersome formats (e.g. RNA) are ongoing, but the first results suggest that there is a need for improvement and further simplification of this methodology.

Collectively, it seems that HIV immunotherapy, although still highly experimental, is a viable option to explore. Although some beneficial effects have been described in untreated individuals, most evidence today argues that more effective immune responses can be induced under HAART coverage. In most trials, potentially favorable $\mathrm{T}$ cell responses were induced, while effects on VL have at best been transient. This limited success should not come as a surprise, since in most cases antigens from one particular or a limited number of HIV strains were used as immunogen and even in those trials, where the "autologous" virus or sequences thereof were used, epitopes from which the immune system had already escaped may have been presented.

To overcome these restrictions, new options are available. One is to immunize with a set of the most conserved, subdominant epitopes, mainly in the structural core genes (i.e. Gag) in order to focus and "teach" T cells to effectively react against at least some determinants which the virus cannot possibly escape from without completely losing infectivity. Obviously, this strategy 
might require repeated immunizations with sufficiently large numbers of different stretches of antigens, in view of the requirement to accommodate the HLA restrictions and to allow $\mathrm{T}$ cell receptor "maturation" by gradual somatic mutations. One such approach was proposed by Letourneau et al. [150]. With these antigens, strong immune responses were already induced both in mice and macaques, using HIV conserved alphavirus replicon DNA and electroporation [151]. A similar approach, focusing on different epitopes was proposed more recently by C. Brander [152]. A second alternative is the so-called mosaic gag approach, where a large number of natural HIV sequences are included by in silico recombination (ftp://ftp-t10.lanl.gov/pub/btk/mozaïek) for maximum coverage of potential T cell epitopes of HIV-1 group $\mathrm{M}$, including potential escape variations $[153,154]$. This approach has successfully been applied in macaques, using DNA + recombinant vaccinia boost [155-157]. Interestingly, this viral construct also induced broad responses in PBMC from HIV-1 B or C infected subjects [157].

The next important question to address is how to deliver this improved antigen in vivo. Clearly, genetic constructs, either plasmid DNA, mRNA or recombinant viruses are suitable. All three formats have advantages and drawbacks as explained. Our own preference goes to mRNA, as it is flexible and clean, can include a large number of antigens and variants, and does not carry any infection or insertional risk or risk for vector-related adverse immune reactions [25]. This safety advantage of mRNA-based vaccines as compared to plasmid DNA or viral vectors is reflected in their classification by the authorities (FDA in the USA and Paul Ehrlich Institute in Germany) as no gene therapy approaches. This relaxes the requirements concerning preclinical toxicology studies in animals [149].

Another feature of mRNA is, however, its biological instability (sensitivity to ubiquitous RNAses); and therefore it has mostly been used to load patient-derived DC ex vivo, a strategy which is not applicable at a larger scale. Recent evidence, however, indicates that mRNA can be chemically stabilized to be injected as "naked" RNA in vivo (e.g. intranodally) and/or formulated with either cationic lipids or positively charged proteins. The latter technologies have been refined over the years, and are now ready for clinical application [158-160].

In addition to the antigen and its format or formulation, further signals may be required to optimize the immune responses. Especially if the format is DNA or RNA, a clearly defined genetic adjuvant is most attractive, as it will restrict the costimulatory effect to the site where the immune response is elicited. Th1-skewing (IL12, IFN- $\gamma$ ), common $\gamma$ chain or cytokines, TNF ligand members or Toll-like receptor ligands have been used with some success [28]. From our review two new candidates emerge: IL-21 [45] and PD-1 blocking agents [161].

The desired clinical outcome of a therapeutic vaccine is to keep the VL under control and restore CD4 T cell counts through CD8 $\mathrm{T}$ cell-mediated suppression of viral re-emergence. However, there are no easy correlates for this protective effect while the patient is still on HAART. A straightforward ELISPOT using a standard subtype B set of peptides provides a first indication of immunogenicity, but it does not represent a true correlate for protection. Expanding the breadth of the $\mathrm{T}$ cell responses by testing many peptide variants, "potential $\mathrm{T}$ cell epitopes" (PTE) [162], increasing avidity by testing low peptide concentrations or improving the "quality" in terms of lytic capacity of CD8 T cells or poly-functionality as well as expansion of HIV-specific effector-memory or central memory CD4 and CD8 $\mathrm{T}$ cells have all been proposed as useful $[6,8]$, but these tests remain somewhat indirect correlates and require rather delicate and cumbersome experimental approaches. As mentioned, several authors, including ourselves, have proposed to measure the vaccine-induced capacity of the patients' CD8 T cells to suppress various HIV isolates in vitro, as this function has repeatedly been associated with the "elite controller" status [18-20,111]. Obviously, this type of functional test is also difficult to standardize, but it has the conceptual advantage of being a direct correlate of the desired protective effect.

Another important parameter to consider is whether immunotherapy or any other intervention aiming at a "functional cure" could reduce the size of the latent reservoir. Several assays have been proposed to measure residual replication-competent virus in purified CD4 $\mathrm{T}$ cells, based on (enhanced) viral culture as well as on an array of PCR-based methods quantifying intracellular viral mRNA (unspliced or multiple spliced) or proviral DNA. With regard to the latter, it is important to determine integrated versus non-integrated proviral DNA as well as the precise cell subset of the reservoir (activated versus resting $\mathrm{T}$ cells, central-memory versus terminally differentiated, macrophages, dendritic cells etc.). Moreover, the measurement should not be limited to blood, but also consider reservoirs in lymphoid tissues (peripheral or gastro-intestinal-associated lymph nodes) as well as "sanctuary sites" (such as the CNS or the genital tract). While the conceptual importance of these measurements is evident, these assays are presently not standardized and it remains to be determined which ones are most predictive of what we really want to know: will our intervention be able to mitigate or abrogate viral rebound after subsequent interruption of HAART $[1,30]$ ?

Since there is no definite ex vivo/in vitro correlate of protection and since the SIV macaque model does not necessarily predict effects in human trials, one needs to 
proceed to a human trial with analytical treatment interruption to assess the ultimate clinical effect. In view of the observed variability in trial outcome, there is a clear requirement for a carefully matched and sufficiently large placebo group. Treatment interruption, even when guided by CD4 $\mathrm{T}$ cell counts and carefully designed to avoid emergence of drug resistance, is being considered as harmful in the long run since the SMART trial [29]. To address this problem, Routy recently reanalyzed the SMART data for the effects of a limited duration of treatment interruption (e.g. 16 weeks) in patients on stable HIV-suppressive HAART with CD4 T counts $>$ $400 / \mu \mathrm{L}$, a CD4 T cell nadir of $>200 / \mu \mathrm{L}$ and without concomitant diseases. He concluded that ATI under those conditions is safe and thus acceptable in the context of a well monitored therapeutic trial with timely resumption of HAART in case of rebound and/or CD4 T cell drop [163].

\section{Abbreviations}

AIDS: Acquired immune deficiency syndrome; ANRS: Agence Nationale de Recherche sur le SIDA; APC: Antigen-presenting cell; AT-2: Aldithriol; ATI: Analytical treatment interruption; CTL: Cytolytic T cell; CTLA-4: Cytolytic T lymphocyte antigen-4; DC: Dendritic cell; EC: Elite controllers; HAART: Highly active antiretroviral therapy; HIV: Human immune deficiency virus; HSC: Hematopoietic stem cells; Id: Intradermal; IFN: Interferon; IL: Interleukin; Im: Intramuscular; ISG: Interferon-stimulated genes; Iv: Intravenous; MVA: Modified vaccinia Ankara; NK: Natural killer; NRTI: Nucleoside reverse transcriptase inhibitor; PBMC: Peripheral blood mononuclear cells; PD1: Programmed death receptor-1; PTC: Post-treatment control; Sc: Subcutaneous; SCID: Severe combined immune deficiency; SIV: Simian immune deficiency virus; STI: Structured treatment interruption; Th: T helper; TI: Treatment interruption; Treg: Regulatory T cell; VL: Viral load; W: Week.

\section{Competing interests}

The authors have no competing interests to declare.

\section{Authors' contributions}

GVH an EVG conceived and wrote the review together. Both authors read and approved the final manuscript.

\section{Acknowledgments}

The authors would like to thank Rafaël Van Den Bergh and Lotte Bracke for carefully correcting and Ciska Maeckelbergh for processing the manuscript. Funding was provided by SOFI (Speciaal Onderzoeksfonds ITG); IAP (Interuniversity Attraction Poles grant no. P6/41) and FWO (Fonds voor Wetenschappelijk Onderzoek Vlaanderen grant no. G.0226.10 N).

\section{Author details}

${ }^{1}$ Virology Unit, Department of Biomedical Sciences, Institute of Tropical Medicine of Antwerp, Nationalestraat 155, B-2000, Antwerpen, Belgium. ${ }^{2}$ Department of Biomedical Sciences, University of Antwerpen, Antwerpen, Belgium. ${ }^{3}$ Present address: Community of Research Excellence and Advanced Technology (C.R.E.A.Te), Division of Janssen, Beerse, Belgium.

Received: 12 June 2012 Accepted: 7 August 2012

Published: 7 September 2012

\section{References}

1. Deeks SG, Autran B, Berkhout B, Benkirane M, Cairns S, Chomont N, Chun TW, Churchill M, Mascio MD, Katlama C, et al: Towards an HIV cure: a global scientific strategy. Nat Rev Immunol 2012, 12:607-614.

2. Hutter $G$, Thiel E: Allogeneic transplantation of CCR5-deficient progenitor cells in a patient with HIV infection: an update after 3 years and the search for patient no. 2. AIDS 2011, 25:273-274.
3. Lafeuillade A, Stevenson M: The Search for a Cure for Persistent HIV Reservoirs. AlDS Rev 2011, 13:63-66.

4. Holt N, Wang J, Kim K, Friedman G, Wang X, Taupin V, Crooks GM, Kohn DB, Gregory PD, Holmes MC, Cannon PM: Human hematopoietic stem/ progenitor cells modified by zinc-finger nucleases targeted to CCR5 control HIV-1 in vivo. Nat Biotechnol 2010, 28:839-847.

5. Kiem HP, Jerome KR, Deeks SG, McCune JM: Hematopoietic-Stem-CellBased Gene Therapy for HIV Disease. Cell Stem Cell 2012, 10:137-147.

6. Chakrabarti LA, Simon V: Immune mechanisms of HIV control. Curr Opin Immunol 2010, 22:488-496.

7. Koup RA, Douek DC: Vaccine design for CD8 T lymphocyte responses. Cold Spring Harb Perspect Med 2011, 1:a007252.

8. Koup RA, Graham BS, Douek DC: The quest for a T cell-based immune correlate of protection against HIV: a story of trials and errors. NatRevimmunol 2011, 11:65-70.

9. Alter G, Heckerman D, Schneidewind A, Fadda L, Kadie CM, Carlson JM, Oniangue-Ndza C, Martin M, Li B, Khakoo SI, et al: HIV-1 adaptation to NKcell-mediated immune pressure. Nature 2011, 476:96-100.

10. Romani L, Puccetti P, Bistoni F: Interleukin-12 in infectious diseases. Clin Microbiol Rev 1997, 10:611-636.

11. Autran B, Descours B, Avettand-Fenoel V, Rouzioux C: Elite controllers as a model of functional cure. Curr Opin HIV AIDS 2011, 6:181-187.

12. Hocqueloux L, Prazuck T, Avettand-Fenoel V, Lafeuillade A, Cardon B, Viard JP, Rouzioux C: Long-term immunovirologic control following antiretroviral therapy interruption in patients treated at the time of primary HIV-1 infection. AIDS 2010, 24:1598-1601.

13. Lodi S, Meyer L, Kelleher AD, Rosinska M, Ghosn J, Sannes M, Porter K. Immunovirologic Control 24 Months After Interruption of Antiretroviral Therapy Initiated Close to HIV Seroconversion. Arch Intern Med 2012, 23:1-4.

14. Van Gulck E, Heyndrickx L, Bracke L, Coppens S, Florence E, Buve A, Lewi P, Vanham G: Control of viral replication after cessation of HAART. AIDS Res Ther 2011, 8:6.

15. Van Gulck E, Bracke L, Heyndrickx L, Coppens S, Atkinson D, Merlin C, Pasternak A, Florence E, Vanham G: Immune and Viral Correlates of "Secondary Viral Control" after Treatment Interruption in Chronically HIV1 Infected Patients. PLoS One 2012, 7:e37792.

16. Kiepiela P, Ngumbela K, Thobakgale C, Ramduth D, Honeyborne I, Moodley E, Reddy S, de Pierres C, Mncube Z, Mkhwanazi N, et al: CD8+ T-cell responses to different HIV proteins have discordant associations with viral load. Nat Med 2007, 13:46-53.

17. Rolland M, Heckerman D, Deng W, Rousseau CM, Coovadia H, Bishop K, Goulder PJ, Walker BD, Brander C, Mullins Jl: Broad and Gag-biased HIV-1 epitope repertoires are associated with lower viral loads. PLoS One 2008, 3:e1424.

18. Hersperger AR, Migueles SA, Betts MR, Connors M: Qualitative features of the HIV-specific CD8+ T-cell response associated with immunologic control. Curr Opin HIV AIDS 2011, 6:169-173.

19. Saez-Cirion A, Shin SY, Versmisse P, Barre-Sinoussi F, Pancino G: Ex vivo T cell-based HIV suppression assay to evaluate HIV-specific CD8+ T-cell responses. Nat Protoc 2010, 5:1033-1041.

20. Spentzou A, Bergin P, Gill D, Cheeseman H, Ashraf A, Kaltsidis H, Cashin-Cox M, Anjarwalla I, Steel A, Higgs C, et al: Viral inhibition assay: a CD8 T cell neutralization assay for use in clinical trials of HIV-1 vaccine candidates. $J$ Infect Dis 2010, 201:720-729.

21. Theze J, Chakrabarti LA, Vingert B, Porichis F, Kaufmann DE: HIV controllers: A multifactorial phenotype of spontaneous viral suppression. Clin Immunol 2011, 4:4.

22. Steinman RM, Granelli-Piperno A, Pope M, Trumpfheller C, Ignatius R, Arrode G, Racz P, Tenner-Racz K: The interaction of immunodeficiency viruses with dendritic cells. Curr Top Microbiol Immunol 2003, 276:1-30.

23. Porichis F, Kaufmann DE: HIV-specific CD4 T cells and immune control of viral replication. Curr Opin HIV AIDS 2011, 6:174-180.

24. Rinaldo CR: Dendritic cell-based human immunodeficiency virus vaccine. J Intern Med 2009, 265:138-158.

25. Van Gulck E, Van Tendeloo VF, Berneman ZN, Vanham G: Role of dendritic cells in HIV-immunotherapy. CurrHIV Res 2010, 8:310-322.

26. Sodora DL, Silvestri G: Immune activation and AIDS pathogenesis. AIDS 2008, 22:439-446.

27. Lichtfuss GF, Hoy J, Rajasuriar R, Kramski M, Crowe SM, Lewin SR: Biomarkers of immune dysfunction following combination antiretroviral therapy for HIV infection. Biomark Med 2011, 5:171-186. 
28. De Keersmaecker B, Thielemans K, Aerts JL: Fighting with the enemy's weapons? the role of costimulatory molecules in HIV. Curr Mol Med 2011, 11:172-196

29. Paton Nl: Treatment interruption strategies: how great are the risks? Curr Opin Infect Dis 2008, 21:25-30.

30. Palmer $\mathrm{S}$, Josefsson L, Coffin JM: HIV reservoirs and the possibility of a cure for HIV infection. J Intern Med 2011, 19:1365-2796.

31. Hakre S, Chavez L, Shirakawa K, Verdin E: HIV latency: experimental systems and molecular models. FEMS Microbiol Rev 2012, 28:1574-6976.

32. Matalon S, Rasmussen TA, Dinarello CA: Histone deacetylase inhibitors for purging HIV-1 from the latent reservoir. Mol Med 2011, 17:466-472.

33. Lewin SR, Evans VA, Elliott JH, Spire B, Chomont N: Finding a cure for HIV: will it ever be achievable? J Int AIDS Soc 2011, 14:4.

34. Shete A, Thakar M, Singh DP, Gangakhedkar R, Gaikwad A, Pawar J, Paranjape R: HIV Antigen-Specific Reactivation of HIV Infection from Cellular Reservoirs: Implications in the Settings of Therapeutic Vaccinations. AIDS Res Hum Retroviruses 2011, 21:21.

35. Jacobson MA, Hardy D, Connick E, Watson J, DeBruin M: Phase 1 trial of a single dose of recombinant human interleukin-12 in human immunodeficiency virus-infected patients with 100-500 CD4 cells/ microL. J Infect Dis 2000, 182:1070-1076.

36. Jacobson MA, Spritzler J, Landay A, Chan E, Katzenstein D, Schock B, Fox L, Roe J, Kundu S, Pollard R: A Phase I, placebo-controlled trial of multi-dose recombinant human interleukin-12 in patients with HIV infection. AIDS 2002, 16:1147-1154.

37. Emery S, Capra WB, Cooper DA, Mitsuyasu RT, Kovacs JA, Vig P, Smolskis M, Saravolatz LD, Lane HC, Fyfe GA, Curtin PT: Pooled analysis of 3 randomized, controlled trials of interleukin-2 therapy in adult human immunodeficiency virus type 1 disease. J Infect Dis 2000, 182:428-434.

38. Abrams D, Levy Y, Losso MH, Babiker A, Collins G, Cooper DA, Darbyshire J, Emery S, Fox L, Gordin F, et al: Interleukin-2 therapy in patients with HIV infection. N Engl J Med 2009, 361:1548-1559.

39. Molina JM, Levy Y, Fournier I, Hamonic S, Bentata M, Beck-Wirth G, Gougeon ML, Venet A, Madelaine I, Sereni D, et al: Interleukin-2 before antiretroviral therapy in patients with HIV infection: a randomized trial (ANRS 119). J Infect Dis 2009, 200:206-215.

40. Levy Y, Thiebaut R, Gougeon ML, Molina JM, Weiss L, Girard PM, Venet A Morlat P, Poirier B, Lascaux AS, et al: Effect of Intermittent Interleukin-2 Therapy on CD4+ T cell counts following antiretroviral cessation in patients with HIV (ANRS 118/NIH 04-I-0018 ILIADE Trial). AIDS 2012, 1:1.

41. Sereti I, Dunham RM, Spritzler J, Aga E, Proschan MA, Medvik K, Battaglia CA, Landay AL, Pahwa S, Fischl MA, et al: IL-7 administration drives T cell-cycle entry and expansion in HIV-1 infection. Blood 2009, 113:6304-6314.

42. Imamichi H, Degray G, Asmuth DM, Fischl MA, Landay AL, Lederman MM, Sereti I: HIV-1 viruses detected during episodic blips following interleukin-7 administration are similar to the viruses present before and after interleukin-7 therapy. AIDS 2011, 25:159-164.

43. Parker R, Dutrieux J, Beq S, Lemercier B, Rozlan S, Fabre-Mersseman V, Rancez M, Gommet C, Assouline B, Rance I, et al: Interleukin-7 treatment counteracts IFN-alpha therapy-induced lymphopenia and stimulates SIVspecific cytotoxic T lymphocyte responses in SIV-infected rhesus macaques. Blood 2010, 116:5589-5599.

44. Lugli E, Mueller YM, Lewis MG, Villinger F, Katsikis PD, Roederer M: Interleukin-15 delays suppression and fails to promote immune reconstitution in virally suppressed chronically SIV-infected macaques. Blood 2011, 14:14.

45. Pallikkuth S, Rogers K, Villinger F, Dosterii M, Vaccari M, Franchini G, Pahwa R, Pahwa S: Interleukin-21 administration to rhesus macaques chronically infected with simian immunodeficiency virus increases cytotoxic effector molecules in T cells and NK cells and enhances B cell function without increasing immune activation or viral replication. Vaccine 2011, 29:9229-9238.

46. Simone R, Piatti G, Saverino D: The inhibitory co-receptors: a way to save from anergy the HIV-specific T cells. Curr HIV Res 2009, 7:266-272.

47. Hryniewicz A, Boasso A, Edghill-Smith Y, Vaccari M, Fuchs D, Venzon D, Nacsa J, Betts MR, Tsai WP, Heraud JM, et al: CTLA-4 blockade decreases TGF-beta, IDO, and viral RNA expression in tissues of SIVmac251-infected macaques. Blood 2006, 108:3834-3842.

48. Cecchinato V, Tryniszewska E, Ma ZM, Vaccari M, Boasso A, Tsai WP, Petrovas C, Fuchs $D$, Heraud JM, Venzon D, et al: Immune activation driven by CTLA-4 blockade augments viral replication at mucosal sites in simian immunodeficiency virus infection. J Immuno/ 2008, 180:5439-5447.
49. Valdez H, Lederman MM: Cytokines and cytokine therapies in HIV infection. AIDS Clin Rev 1998, 187-228.

50. Lane HC, Davey V, Kovacs JA, Feinberg J, Metcalf JA, Herpin B, Walker R, Deyton L, Davey RT Jr, Falloon J, et al: Interferon-alpha in patients with asymptomatic human immunodeficiency virus (HIV) infection. A randomized, placebo-controlled trial. Ann Intern Med 1990, 112:805-811.

51. Gringeri A, Musicco M, Hermans P, Bentwich Z, Cusini M, Bergamasco A, Santagostino E, Burny A, Bizzini B, Zagury D: Active anti-interferon-alpha immunization: a European-Israeli, randomized, double-blind, placebocontrolled clinical trial in $242 \mathrm{HIV}$-1-infected patients (the EURIS study). J Acquir Immune Defic Syndr Hum Retrovirol 1999, 20:358-370.

52. Ries M, Pritschet K, Schmidt B: Blocking Type I Interferon Production: A New Therapeutic Option to Reduce the HIV-1-Induced Immune Activation. Clin Dev Immunol 2012, 2012:534929.

53. Paton NI, Goodall RL, Dunn DT, Franzen S, Collaco-Moraes Y, Gazzard BG, Williams IG, Fisher MJ, Winston A, Fox J, et al: Effects of hydroxychloroquine on immune activation and disease progression among HIV-infected patients not receiving antiretroviral therapy: a randomized controlled trial. JAMA 2012, 308:353-361.

54. Clerici M, Shearer GM: A TH1-> TH2 switch is a critical step in the etiology of HIV infection. Immunol Today 1993, 14:107-111.

55. Clerici M, Lucey DR, Berzofsky JA, Pinto LA, Wynn TA, Blatt SP, Dolan MJ, Hendrix CW, Wolf SF, Shearer GM: Restoration of HIV-specific cellmediated immune responses by interleukin-12 in vitro. Science 1993, 262:1721-1724.

56. Landay AL, Clerici M, Hashemi F, Kessler H, Berzofsky JA, Shearer GM: In vitro restoration of $T$ cell immune function in human immunodeficiency virus-positive persons: effects of interleukin (IL)-12 and anti-IL-10. J Infect Dis 1996, 173:1085-1091.

57. Koblish HK, Hunter CA, Wysocka M, Trinchieri G, Lee WM: Immune suppression by recombinant interleukin (rIL)-12 involves interferon gamma induction of nitric oxide synthase 2 (iNOS) activity: inhibitors of NO generation reveal the extent of rIL-12 vaccine adjuvant effect. J Exp Med 1998, 188:1603-1610.

58. Gherardi MM, Ramirez JC, Esteban M: Interleukin-12 (IL-12) enhancement of the cellular immune response against human immunodeficiency virus type 1 env antigen in a DNA prime/vaccinia virus boost vaccine regimen is time and dose dependent: suppressive effects of IL-12 boost are mediated by nitric oxide. J Virol 2000, 74:6278-6286.

59. Rochman $Y$, Spolski R, Leonard WJ: New insights into the regulation of $T$ cells by gamma(c) family cytokines. Nat Rev Immunol 2009, 9:480-490.

60. Sirskyj D, Theze J, Kumar A, Kryworuchko M: Disruption of the gamma c cytokine network in T cells during HIV infection. Cytokine 2008, 43:1-14.

61. Cheng G, Yu A, Malek TR: T-cell tolerance and the multi-functional role of IL-2R signaling in T-regulatory cells. Immunol Rev 2011, 241:63-76.

62. Kirkpatrick CH, Davis KC, Horsburgh CR Jr, Cohn DL, Penley K, Judson FN: Interleukin-2 production by persons with the generalized lymphadenopathy syndrome or the acquired immune deficiency syndrome. J Clin Immunol 1985, 5:31-37.

63. Fahey JL, Giorgi J, Martinez-Maza O, Detels R, Mitsuyasu R, Taylor J: Immune pathogenesis of AIDS and related syndromes. Ann Inst Pasteur Immunol 1987, 138:245-252.

64. Gougeon ML, Chiodi F: Impact of gamma-chain cytokines on T cell homeostasis in HIV-1 infection: therapeutic implications. J Intern Med 2010, 267:502-514.

65. Ahmad A, Ahmad R, lannello A, Toma E, Morisset R, Sindhu ST: IL-15 and HIV infection: lessons for immunotherapy and vaccination. Curr HIV Res 2005, 3:261-270

66. Iannello A, Tremblay C, Routy JP, Boulassel MR, Toma E, Ahmad A: Decreased levels of circulating IL-21 in HIV-infected AIDS patients: correlation with CD4+ T-cell counts. Viral Immunol 2008, 21:385-388.

67. Mueller YM, Katsikis PD: IL-15 in HIV infection: pathogenic or therapeutic potential? Eur Cytokine Netw 2010, 21:219-221. Epub 2010 Aug 2019.

68. Li S, Qi X, Gao Y, Hao Y, Cui L, Ruan L, He W: IL-15 increases the frequency of effector memory CD8+ T cells in rhesus monkeys immunized with HIV vaccine. Cell Mol Immunol 2010, 7:491-494.

69. Parmigiani A, Pallin MF, Schmidtmayerova H, Lichtenheld MG, Pahwa S: Interleukin-21 and cellular activation concurrently induce potent cytotoxic function and promote antiviral activity in human CD8 T cells. Hum Immunol 2011, 72:115-123. 
70. lannello A, Boulassel MR, Samarani S, Tremblay C, Toma E, Routy JP, Ahmad A: IL-21 enhances NK cell functions and survival in healthy and HIV-infected patients with minimal stimulation of viral replication. J Leukoc Biol 2010, 87:857-867.

71. White L, Krishnan S, Strbo N, Liu H, Kolber MA, Lichtenheld MG, Pahwa RN, Pahwa S: Differential effects of IL-21 and IL-15 on perforin expression, lysosomal degranulation, and proliferation in CD8 T cells of patients with human immunodeficiency virus-1 (HIV). Blood 2007, 109:3873-3880.

72. Strbo N, de Armas L, Liu H, Kolber MA, Lichtenheld M, Pahwa S: IL-21 augments natural killer effector functions in chronically HIV-infected individuals. AIDS 2008, 22:1551-1560

73. Chevalier MF, Julg B, Pyo A, Flanders M, Ranasinghe S, Soghoian DZ, Kwon DS, Rychert J, Lian J, Muller Ml, et al: HIV-1-specific interleukin-21+ CD4+ T cell responses contribute to durable viral control through the modulation of HIV-specific CD8+ T cell function. J Virol 2011, 85:733-741.

74. Shankar EM, Che KF, Messmer D, Lifson JD, Larsson M: Expression of a Broad Array of Negative Costimulatory Molecules and Blimp-1 in T-cells Following Priming by HIV-1 Pulsed Dendritic Cells. MolMed 2010, 17:229-240.

75. Kaufmann DE, Walker BD: PD-1 and CTLA-4 inhibitory cosignaling pathways in HIV infection and the potential for therapeutic intervention. $\mathrm{J}$ Immunol 2009, 182:5891-5897.

76. Porichis F, Kaufmann DE: Role of PD-1 in HIV Pathogenesis and as Target for Therapy. Curr HIV/AIDS Rep 2011, 24:24.

77. Dyavar Shetty R, Velu V, Titanji K, Bosinger SE, Freeman GJ, Silvestri G, Amara RR: PD-1 blockade during chronic SIV infection reduces hyperimmune activation and microbial translocation in rhesus macaques. J Clin Invest 2012, 122:1712-1716.

78. Fernandez-Cruz E, Navarro J, Rodriguez-Sainz C, Gil J, Moreno S, GonzalezLahoz J, Carbone J: The potential role of the HIV-1 immunogen (Remune) as a therapeutic vaccine in the treatment of HIV infection. Expert ReV Vaccines 2003, 2:739-752

79. Chantratita W, Sukeepaisarncharoen W, Chandeying V, Kulpradist S, Israngkura Na Ayudhtaya B, Rugpao S, Sirawaraporn W, Boonshuyar C, Churdboonchart $\mathrm{V}$ : Delayed progression to AIDS in volunteers treated with long-term HIV-1 Immunogen (REMUNE) therapy in Thailand. HIV Med 2004, 5:317-325.

80. Kinloch-de Loes S, Hoen B, Smith DE, Autran B, Lampe FC, Phillips AN, Goh LE, Andersson J, Tsoukas C, Sonnerborg A, et al: Impact of therapeutic immunization on HIV-1 viremia after discontinuation of antiretroviral therapy initiated during acute infection. J Infect Dis 2005, 192:607-617.

81. Rosati M, von Gegerfelt A, Roth P, Alicea C, Valentin A, Robert-Guroff M, Venzon D, Montefiori DC, Markham P, Felber BK, Pavlakis GN: DNA vaccines expressing different forms of simian immunodeficiency virus antigens decrease viremia upon SIVmac251 challenge. J Virol 2005, 79:8480-8492.

82. Rosati M, Bergamaschi C, Valentin A, Kulkarni V, Jalah R, Alicea C, Patel V, von Gegerfelt AS, Montefiori DC, Venzon DJ, et al: DNA vaccination in rhesus macaques induces potent immune responses and decreases acute and chronic viremia after SIVmac251 challenge. Proc Natl Acad Sci US A 2009, 106:15831-15836.

83. Wilson CC, Newman MJ, Livingston BD, MaWhinney S, Forster JE, Scott J, Schooley RT, Benson CA: Clinical phase 1 testing of the safety and immunogenicity of an epitope-based DNA vaccine in human immunodeficiency virus type 1-infected subjects receiving highly active antiretroviral therapy. Clin Vaccine Immunol 2008, 15:986-994.

84. Rosenberg ES, Graham BS, Chan ES, Bosch RJ, Stocker V, Maenza J, Markowitz M, Little S, Sax PE, Collier AC, et al: Safety and immunogenicity of therapeutic DNA vaccination in individuals treated with antiretroviral therapy during acute/early HIV-1 infection. PLoS One 2010, 5:e10555.

85. Gudmundsdotter L, Wahren B, Haller BK, Boberg A, Edback U, Bernasconi D, Butto S, Gaines H, Imami N, Gotch F, et al: Amplified antigen-specific immune responses in HIV-1 infected individuals in a double blind DNA immunization and therapy interruption trial. Vaccine 2011, 29:5558-5566.

86. Tubiana R, Carcelain G, Vray M, Gourlain K, Dalban C, Chermak A, Rabian C,

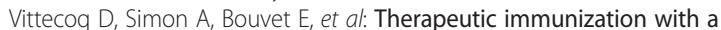
human immunodeficiency virus (HIV) type 1-recombinant canarypox vaccine in chronically HIV-infected patients: The Vacciter Study (ANRS 094). Vaccine 2005, 23:4292-4301

87. Levy Y, Gahery-Segard H, Durier C, Lascaux AS, Goujard C, Meiffredy V, Rouzioux C, El Habib R, Beumont-Mauviel M, Guillet JG, et al: Immunological and virological efficacy of a therapeutic immunization combined with interleukin-2 in chronically HIV-1 infected patients. AIDS 2005, 19:279-286.

88. Kilby JM, Bucy RP, Mildvan D, Fischl M, Santana-Bagur J, Lennox J, Pilcher C Zolopa A, Lawrence J, Pollard RB, et al: A randomized, partially blinded phase 2 trial of antiretroviral therapy, HIV-specific immunizations, and interleukin-2 cycles to promote efficient control of viral replication (ACTG A5024). J Infect Dis 2006, 194:1672-1676.

89. Angel JB, Routy JP, Tremblay C, Ayers D, Woods R, Singer J, Bernard N, Kovacs C, Smaill F, Gurunathan S, Sekaly RP: A randomized controlled trial of HIV therapeutic vaccination using ALVAC with or without Remune. AIDS 2011, 25:731-739.

90. Autran B, Murphy RL, Costagliola D, Tubiana R, Clotet B, Gatell J, Staszewski S, Wincker N, Assoumou L, El-Habib R, et al: Greater viral rebound and reduced time to resume antiretroviral therapy after therapeutic immunization with the ALVAC-HIV vaccine (vCP1452). AIDS 2008, 22:1313-1322.

91. Emery S, Workman C, Puls RL, Bloch M, Baker D, Bodsworth N, Anderson J, Crowe SM, French MA, Hoy J, et al: Randomized, placebo-controlled, phase I/lla evaluation of the safety and immunogenicity of fowlpox virus expressing HIV gag-pol and interferon-gamma in HIV-1 infected subjects. Hum Vaccin 2005, 1:232-238.

92. Emery S, Kelleher AD, Workman C, Puls RL, Bloch M, Baker D, Anderson J, Hoy J, Ip S, Nalliah K, et al: Influence of IFNgamma co-expression on the safety and antiviral efficacy of recombinant fowlpox virus HIV therapeutic vaccines following interruption of antiretroviral therapy. Hum Vaccin 2007, 3:260-267.

93. Uberla K, Rosenwirth B, Ten Haaft P, Heeney J, Sutter G, Erfle V: Therapeutic immunization with Modified Vaccinia Virus Ankara (MVA) vaccines in SIV-infected rhesus monkeys undergoing antiretroviral therapy. J Med Primatol 2007, 36:2-9.

94. Shimada M, Wang HB, Kondo A, Xu XP, Yoshida A, Shinoda K, Ura T, Mizuguchi $H$, Klinman D, Luo JL, et al: Effect of therapeutic immunization using Ad5/35 and MVA vectors on SIV infection of rhesus monkeys undergoing antiretroviral therapy. Gene Ther 2009, 16:218-228.

95. Harrer E, Bauerle M, Ferstl B, Chaplin P, Petzold B, Mateo L, Handley A, Tzatzaris M, Vollmar J, Bergmann S, et al: Therapeutic vaccination of HIV-1infected patients on HAART with a recombinant HIV-1 nef-expressing MVA: safety, immunogenicity and influence on viral load during treatment interruption. Antivir Ther 2005, 10:285-300.

96. Dorrell L, Yang H, Ondondo B, Dong T, di Gleria K, Suttill A, Conlon C, Brown D, Williams $P$, Bowness $P$, et al: Expansion and diversification of virus-specific $T$ cells following immunization of human immunodeficiency virus type 1 (HIV-1)-infected individuals with a recombinant modified vaccinia virus Ankara/HIV-1 Gag vaccine. J Virol 2006, 80:4705-4716.

97. Dorrell L, Williams P, Suttill A, Brown D, Roberts J, Conlon C, Hanke T, McMichael A: Safety and tolerability of recombinant modified vaccinia virus Ankara expressing an HIV-1 gag/multiepitope immunogen (MVA. HIVA) in HIV-1-infected persons receiving combination antiretroviral therapy. Vaccine 2007, 25:3277-3283.

98. Soloff AC, Liu X, Gao W, Day RD, Gambotto A, Barratt-Boyes SM: Adenovirus 5- and 35-based immunotherapy enhances the strength but not breadth or quality of immunity during chronic SIV infection. Eur J Immunol 2009, 39:2437-2449

99. Schooley RT, Spritzler J, Wang H, Lederman MM, Havlir D, Kuritzkes DR, Pollard R, Battaglia C, Robertson M, Mehrotra D, et al: AIDS clinical trials group 5197: a placebo-controlled trial of immunization of HIV-1-infected persons with a replication-deficient adenovirus type 5 vaccine expressing the HIV-1 core protein. J Infect Dis 2010, 202:705-716.

100. Kundu SK, Engleman E, Benike C, Shapero MH, Dupuis M, van Schooten WC, Eibl M, Merigan TC: A pilot clinical trial of HIV antigen-pulsed allogeneic and autologous dendritic cell therapy in HIV-infected patients. AIDS Res Hum Retroviruses 1998, 14:551-560.

101. Ide F, Nakamura T, Tomizawa M, Kawana-Tachikawa A, Odawara T, Hosoya N, Iwamoto A: Peptide-loaded dendritic-cell vaccination followed by treatment interruption for chronic HIV-1 infection: a phase 1 trial. J Med Virol 2006, 78:711-718.

102. De Rose R, Fernandez CS, Smith MZ, Batten CJ, Alcantara S, Peut V, Rollman E, Loh $\mathrm{L}$, Mason RD, Wilson $\mathrm{K}$, et al: Control of viremia and prevention of AIDS following immunotherapy of SIV-infected macaques with peptide-pulsed blood. PLOS Pathog 2008, 4:e1000055 
103. Lu W, Wu X, Lu Y, Guo W, Andrieu JM: Therapeutic dendritic-cell vaccine for simian AIDS. Nat Med 2003, 9:27-32.

104. Lu W, Arraes LC, Ferreira WT, Andrieu JM: Therapeutic dendritic-cell vaccine for chronic HIV-1 infection. Nat Med 2004, 10:1359-1365.

105. Garcia F, Ruiz L, de Quiros JC L-B, Moreno S, Domingo P: Immunotherapy and therapeutic vaccines in HIV infection. Enferm Infecc Microbiol Clin 2005, 23(Suppl 2):84-104

106. Garcia F, Climent N, Assoumou L, Gil C, Gonzalez N, Alcami J, Leon A, Romeu J, Dalmau J, Martinez-Picado J, et al: A Therapeutic Dendritic CellBased Vaccine for HIV-1 Infection. J Infect Dis 2010, 203:473-478.

107. Gandhi RT, O'Neill D, Bosch RJ, Chan ES, Bucy RP, Shopis J, Baglyos L, Adams $E$, Fox $L$, Purdue $L$, et al: $A$ randomized therapeutic vaccine trial of canarypox-HIV-pulsed dendritic cells vs. canarypox-HIV alone in HIV-1infected patients on antiretroviral therapy. Vaccine 2009, 27:6088-6094.

108. Routy JP, Boulassel MR, Yassine-Diab B, Nicolette C, Healey D, Jain R, Landry C, Yegorov O, Tcherepanova I, Monesmith T, et al: Immunologic activity and safety of autologous HIV RNA-electroporated dendritic cells in HIV-1 infected patients receiving antiretroviral therapy. Clin Immunol 2010, 134:140-147

109. Routy JP, Nicolette C: Arcelis AGS-004 dendritic cell-based immunotherapy for HIV infection. Immunotherapy 2010, 2:467-476.

110. Allard SD, De Keersmaecker B, de Goede AL, Verschuren EJ, Koetsveld J, Reedijk ML, Wylock C, De Bel AV, Vandeloo J, Pistoor F, et al: A Phase I/Ila Immunotherapy Trial of HIV-1-Infected Patients with Tat, Rev and Nef expressing dendritic cells followed by treatment interruption. Clin Immunol 2012, 142:252-268.

111. Van Gulck E, Vlieghe E, Vekemans M, Van Tendeloo VF, Van De Velde A, Smits E, Anguille S, Cools N, Goossens H, Mertens L, et al: mRNA-based dendritic cell vaccination induces potent antiviral T-cell responses in HIV-1-infected patients. AIDS 2012, 26:F1-F12.

112. Limsuwan $A$, Churdboonchart V, Moss RB, Sirawaraporn W, Sutthent R, Smutharaks B, Glidden D, Trauger R, Theofan G, Carlo D: Safety and immunogenicity of REMUNE in HIV-infected Thai subjects. Vaccine 1998, 16:142-149.

113. von Gegerfelt AS, Rosati M, Alicea C, Valentin A, Roth P, Bear J, Franchini G, Albert PS, Bischofberger N, Boyer JD, et al: Long-lasting decrease in viremia in macaques chronically infected with simian immunodeficiency virus SIVmac251 after therapeutic DNA immunization. J Virol 2007 81:1972-1979.

114. Valentin A, von Gegerfelt A, Rosati M, Miteloudis G, Alicea C, Bergamaschi C, Jalah R, Patel V, Khan AS, Draghia-Akli R, et al: Repeated DNA therapeutic vaccination of chronically SIV-infected macaques provides additional virological benefit. Vaccine 2010, 28:1962-1974.

115. Lori F: DermaVir: a plasmid DNA-based nanomedicine therapeutic vaccine for the treatment of HIV/AIDS. Expert Rev Vaccines 2011, 10:1371-1384.

116. Lisziewicz J, Bakare N, Calarota SA, Banhegyi D, Szlavik J, Ujhelyi E, Toke ER, Molnar L, Lisziewicz Z, Autran B, Lori F: Single DermaVir Immunization: Dose-Dependent Expansion of Precursor/Memory $T$ Cells against All HIV Antigens in HIV-1 Infected Individuals. PLOS One 2012, 7:e35416

117. Kim JJ, Nottingham LK, Tsai A, Lee DJ, Maguire HC, Oh J, Dentchev T, Manson KH, Wyand MS, Agadjanyan MG, et al: Antigen-specific humoral and cellular immune responses can be modulated in rhesus macaques through the use of IFN-gamma, IL-12, or IL-18 gene adjuvants. J Med Primatol 1999, 28:214-223.

118. Halwani R, Boyer JD, Yassine-Diab B, Haddad EK, Robinson TM, Kumar S, Parkinson R, Wu L, Sidhu MK, Phillipson-Weiner R, et al: Therapeutic vaccination with simian immunodeficiency virus (SIV)-DNA + IL-12 or IL15 induces distinct CD8 memory subsets in SIV-infected macaques. J Immunol 2008, 180:7969-7979.

119. Boyer JD, Cohen AD, Ugen KE, Edgeworth RL, Bennett M, Shah A, Schumann K, Nath B, Javadian A, Bagarazzi ML, et al: Therapeutic immunization of HIV-infected chimpanzees using HIV-1 plasmid antigens and interleukin-12 expressing plasmids. AIDS 2000, 14:1515-1522.

120. Hirao LA, Wu L, Khan AS, Hokey DA, Yan J, Dai A, Betts MR, Draghia-Akli R, Weiner DB: Combined effects of IL-12 and electroporation enhances the potency of DNA vaccination in macaques. Vaccine 2008, 26:3112-3120.

121. Kalams SA, Parker S, Jin X, Elizaga M, Metch B, Wang M, Hural J, Lubeck M Eldridge J, Cardinali M, et al: Safety and Immunogenicity of an HIV-1 Gag DNA Vaccine with or without IL-12 and/or IL-15 Plasmid Cytokine Adjuvant in Healthy, HIV-1 Uninfected Adults. PLoS One 2012, 7:e29231.
122. Vasan S, Hurley A, Schlesinger SJ, Hannaman D, Gardiner DF, Dugin DP, Boente-Carrera M, Vittorino R, Caskey M, Andersen J, et al: In Vivo Electroporation Enhances the Immunogenicity of an HIV-1 DNA Vaccine Candidate in Healthy Volunteers. PLoS One 2011, 6:e19252.

123. Hallengard D, Haller BK, Maltais AK, Gelius E, Nihlmark K, Wahren B, Brave A: Comparison of plasmid vaccine immunization schedules using intradermal in vivo electroporation. Clin Vaccine Immunol 2011, 18:1577-1581.

124. Rerks-Ngarm S, Pitisuttithum P, Nitayaphan S, Kaewkungwal J, Chiu J, Paris R, Premsri N, Namwat C, de Souza M, Adams E, et al: Vaccination with ALVAC and AIDSVAX to prevent HIV-1 infection in Thailand. N Engl J Med 2009, 361:2209-2220.

125. Papagno L, Alter G, Assoumou L, Murphy RL, Garcia F, Clotet B, Larsen M, Braibant M, Marcelin AG, Costagliola D, et al: Comprehensive analysis of virus-specific T-cells provides clues for the failure of therapeutic immunization with ALVAC-HIV vaccine. AIDS 2011, 25:27-36.

126. Frahm N, Decamp AC, Friedrich DP, Carter DK, Defawe OD, Kublin JG, Casimiro DR, Duerr A, Robertson MN, Buchbinder SP, et al: Human adenovirus-specific T cells modulate HIV-specific T cell responses to an Ad5-vectored HIV-1 vaccine. J Clin Invest 2012, 122:359-367. doi:310.1172/ JCl60202.

127. French MA, Tanaskovic S, Law MG, Lim A, Fernandez S, Ward LD, Kelleher AD, Emery S: Vaccine-induced IgG2 anti-HIV p24 is associated with control of HIV in patients with a 'high-affinity' FcgammaRlla genotype. AIDS 2010, 24:19831990.

128. Wang SW, Bertley FM, Kozlowski PA, Herrmann L, Manson K, Mazzara G, Piatak M, Johnson RP, Carville A, Mansfield K, Aldovini A: An SHIV DNA/ MVA rectal vaccination in macaques provides systemic and mucosal virus-specific responses and protection against AIDS. AIDS Res Hum Retroviruses 2004, 20:846-859.

129. Bertley FM, Kozlowski PA, Wang SW, Chappelle J, Patel J, Sonuyi O, Mazzara G, Montefiori D, Carville A, Mansfield KG, Aldovini A: Control of simian/human immunodeficiency virus viremia and disease progression after IL-2augmented DNA-modified vaccinia virus Ankara nasal vaccination in nonhuman primates. J Immunol 2004, 172:3745-3757.

130. Makitalo B, Lundholm P, Hinkula J, Nilsson C, Karlen K, Morner A, Sutter G, Erfle V, Heeney JL, Wahren B, et al: Enhanced cellular immunity and systemic control of SHIV infection by combined parenteral and mucosal administration of a DNA prime MVA boost vaccine regimen. J Gen Virol 2004, 85:2407-2419.

131. Amara RR, Ibegbu C, Villinger F, Montefiori DC, Sharma S, Nigam $P, X u$ Y, McClure HM, Robinson HL: Studies using a viral challenge and CD8 T cell depletions on the roles of cellular and humoral immunity in the control of an SHIV-89.6P challenge in DNA/MVA-vaccinated macaques. Virology 2005, 343:246-255.

132. Precopio ML, Betts MR, Parrino J, Price DA, Gostick E, Ambrozak DR, Asher TE, Douek DC, Harari A, Pantaleo G, et al: Immunization with vaccinia virus induces polyfunctional and phenotypically distinctive CD8(+) T cell responses. J Exp Med 2007, 204:1405-1416.

133. Greenough TC, Cunningham CK, Muresan P, McManus M, Persaud D, Fenton T, Barker P, Gaur A, Panicali D, Sullivan JL, Luzuriaga K: Safety and immunogenicity of recombinant poxvirus HIV-1 vaccines in young adults on highly active antiretroviral therapy. Vaccine 2008, 26:6883-6893

134. Climent N, Guerra S, Garcia F, Rovira C, Miralles L, Gomez CE, Pique N, Gil C, Gatell JM, Esteban M, Gallart T: Dendritic Cells Exposed to MVA-Based HIV1 Vaccine Induce Highly Functional HIV-1-Specific CD8 T Cell Responses in HIV-1-Infected Individuals. PLOS One 2011, 6:e19644

135. Gray G, Buchbinder S, Duerr A: Overview of STEP and Phambili trial results: two phase $\mathrm{Ilb}$ test-of-concept studies investigating the efficacy of MRK adenovirus type $5 \mathrm{gag} / \mathrm{pol} /$ nef subtype B HIV vaccine. Curr Opin HIV AIDS 2010, 5:357-361.

136. Benlahrech A, Harris J, Meiser A, Papagatsias T, Hornig J, Hayes P, Lieber A, Athanasopoulos T, Bachy V, Csomor $E$, et al: Adenovirus vector vaccination induces expansion of memory CD4 T cells with a mucosal homing phenotype that are readily susceptible to HIV-1. Proc Natl Acad Sci U S A 2009, 106:19940-19945.

137. Michael NL: Rare serotype adenoviral vectors for HIV vaccine development. J Clin Invest 2012, 122:25-27.

138. Koup RA, Roederer M, Lamoreaux L, Fischer J, Novik L, Nason MC, Larkin BD, Enama ME, Ledgerwood JE, Bailer RT, et al: Priming immunization with DNA augments immunogenicity of recombinant adenoviral vectors for 
both HIV-1 specific antibody and T-cell responses. PLoS One 2010, 5:e9015.

139. Freel SA, Lamoreaux L, Chattopadhyay PK, Saunders K, Zarkowsky D, Overman RG, Ochsenbauer C, Edmonds TG, Kappes JC, Cunningham CK, et a: Phenotypic and functional profile of HIV-inhibitory CD8 T cells elicited by natural infection and heterologous prime/boost vaccination. J Virol 2010, 84:4998-5006

140. Pillai VK, Kannanganat S, Penaloza-Macmaster P, Chennareddi L, Robinson HL, Blackwell J, Amara RR: Different patterns of expansion, contraction and memory differentiation of HIV-1 Gag-specific CD8 T cells elicited by adenovirus type 5 and modified vaccinia Ankara vaccines. Vaccine 2011, 29:5399-5406.

141. Lapenta C, Santini SM, Logozzi M, Spada M, Andreotti M, Di Pucchio T, Parlato S, Belardelli F: Potent immune response against HIV-1 and protection from virus challenge in hu-PBL-SCID mice immunized with inactivated virus-pulsed dendritic cells generated in the presence of IFNalpha. J Exp Med 2003, 198:361-367.

142. Yoshida A, Tanaka R, Murakami T, Takahashi Y, Koyanagi Y, Nakamura M, Ito M, Yamamoto N, Tanaka Y: Induction of protective immune responses against R5 human immunodeficiency virus type 1 (HIV-1) infection in hu-PBL-SCID mice by intrasplenic immunization with HIV-1-pulsed dendritic cells: possible involvement of a novel factor of human CD4(+) T-cell origin. J Virol 2003, 77:8719-8728.

143. Jonuleit H, Wiedemann K, Muller G, Degwert J, Hoppe U, Knop J, Enk AH: Induction of IL-15 messenger RNA and protein in human blood-derived dendritic cells: a role for IL-15 in attraction of T cells. J Immunol 1997, 158:2610-2615.

144. Van Tendeloo VF, Ponsaerts P, Lardon F, Nijs G, Lenjou M, Van Broeckhoven C, Van Bockstaele DR, Berneman ZN: Highly efficient gene delivery by mRNA electroporation in human hematopoietic cells: superiority to lipofection and passive pulsing of mRNA and to electroporation of plasmid CDNA for tumor antigen loading of dendritic cells. Blood 2001, 98:49-56.

145. Garcia F: 'Functional cure' of HIV infection: the role of immunotherapy. Immunotherapy 2012, 4:245-248.

146. Ahlers JD, Belyakov IM: Strategies for recruiting and targeting dendritic cells for optimizing HIV vaccines. Trends Mol Med 2009, 15:263-274.

147. Trumpfheller C, Longhi MP, Caskey M, Idoyaga J, Bozzacco L, Keler T, Schlesinger SJ, Steinman RM: Dendritic cell-targeted protein vaccines: a novel approach to induce T cell immunity. J Intern Med 2011, 29:1365-2796.

148. Hutnick NA, Myles DJ, Bian CB, Muthumani K, Weiner DB: Selected approaches for increasing HIV DNA vaccine immunogenicity in vivo. Curr Opin Virol 2011, 1:233-240.

149. Weide B, Garbe C, Rammensee HG, Pascolo S: Plasmid DNA- and messenger RNA-based anti-cancer vaccination. Immunol Lett 2008, 115:33-42.

150. Letourneau S, Im EJ, Mashishi T, Brereton C, Bridgeman A, Yang H, Dorrell L, Dong T, Korber B, McMichael AJ, Hanke T: Design and pre-clinical evaluation of a universal HIV-1 vaccine. PLOS One 2007, 2:e984.

151. Knudsen ML, Mbewe-Mvula A, Rosario M, Johansson DX, Kakoulidou M, Bridgeman A, Reyes-Sandoval A, Nicosia A, Ljungberg K, Hanke T, Liljestrom P: Superior Induction of T Cell Responses to Conserved HIV-1 Regions by Electroporated Alphavirus Replicon DNA Compared to That with Conventional Plasmid DNA Vaccine. J Virol 2012, 86:4082-4090.

152. Mothe B, Llano A, Ibarrondo J, Daniels M, Miranda C, Zamarreno J, Bach V, Zuniga R, Perez-Alvarez S, Berger $C$, et al: Definition of the viral targets of protective HIV-1-specific T cell responses. J Trans/ Med 2011, 9:208.

153. Fischer W, Perkins S, Theiler J, Bhattacharya T, Yusim K, Funkhouser R, Kuiken C, Haynes B, Letvin NL, Walker BD, et al: Polyvalent vaccines for optimal coverage of potential T-cell epitopes in global HIV-1 variants. Nat Med 2007, 13:100-106.

154. Thurmond J, Yoon H, Kuiken C, Yusim K, Perkins S, Theiler J, Bhattacharya T, Korber B, Fischer W: Web-based design and evaluation of T-cell vaccine candidates. Bioinformatics 2008, 24:1639-1640.

155. Barouch DH, O'Brien KL, Simmons NL, King SL, Abbink P, Maxfield LF, Sun YH, La Porte A, Riggs AM, Lynch DM, et al: Mosaic HIV-1 vaccines expand the breadth and depth of cellular immune responses in rhesus monkeys. Nat Med 2010, 16:319-323.

156. Santra S, Liao HX, Zhang R, Muldoon M, Watson S, Fischer W, Theiler J, Szinger J, Balachandran H, Buzby A, et al: Mosaic vaccines elicit CD8+ T lymphocyte responses that confer enhanced immune coverage of diverse HIV strains in monkeys. Nat Med 2010, 16:324-328.
157. Ndhlovu ZM, Piechocka-Trocha A, Vine S, McMullen A, Koofhethile KC, Goulder PJ, Ndung'u T, Barouch DH, Walker BD: Mosaic HIV-1 Gag Antigens Can Be Processed and Presented to Human HIV-Specific CD8+ T Cells. J Immunol 2011, 186:6914-6924.

158. Van Lint S, Goyvaerts C, Maenhout S, Goethals L, Disy A, Benteyn D, Pen J, Bonehill A, Heirman C, Breckpot K, Thielemans K: Preclinical evaluation of TriMix and antigen mRNA-based antitumor therapy. Cancer Res 2012, 72:1661-1671.

159. Pascolo S: Vaccination with messenger RNA (mRNA). Handb Exp Pharmacol 2008, 221-235.

160. Fotin-Mleczek M, Duchardt KM, Lorenz C, Pfeiffer R, Ojkic-Zrna S, Probst J, Kallen KJ: Messenger RNA-based vaccines with dual activity induce balanced TLR-7 dependent adaptive immune responses and provide antitumor activity. J Immunother 2011, 34:1-15.

161. Dai B, Xiao L, Bryson PD, Fang J, Wang P: PD-1/PD-L1 Blockade Can Enhance HIV-1 Gag-specific T Cell Immunity Elicited by Dendritic CellDirected Lentiviral Vaccines. Mol Ther 2012, 15:98.

162. Li F, Malhotra U, Gilbert PB, Hawkins NR, Duerr AC, McElrath JM, Corey L, Self SG: Peptide selection for human immunodeficiency virus type 1 CTLbased vaccine evaluation. Vaccine 2006, 24:6893-6904

163. Routy JP, Boulassel MR, Nicolette CA, Jacobson JM: Assessing risk of a short-term antiretroviral therapy discontinuation as a read-out of viral control in immune-based therapy. J Med Virol 2012, 84:885-889.

doi:10.1186/1742-4690-9-72

Cite this article as: Vanham and Van Gulck: Can immunotherapy be useful as a "functional cure" for infection with Human Immunodeficiency Virus-1?. Retrovirology 2012 9:72

\section{Submit your next manuscript to BioMed Central and take full advantage of:}

- Convenient online submission

- Thorough peer review

- No space constraints or color figure charges

- Immediate publication on acceptance

- Inclusion in PubMed, CAS, Scopus and Google Scholar

- Research which is freely available for redistribution 